\title{
Climatic history of the northeastern United States during the past 3000 years
}

Jennifer R. Marlon ${ }^{1}$, Neil Pederson ${ }^{2}$, Connor Nolan $^{3}$, Simon Goring $^{4}$, Bryan Shuman $^{5}$, Ann Robertson ${ }^{1}$, Robert Booth $^{6}$, Patrick J. Bartlein ${ }^{7}$, Melissa A. Berke ${ }^{8}$, Michael Clifford ${ }^{9}$, Edward Cook $^{10}$, Ann Dieffenbacher-Krall ${ }^{11}$, Michael C. Dietze ${ }^{12}$, Amy Hessl ${ }^{13}$, J. Bradford Hubeny ${ }^{14}$, Stephen T. Jackson ${ }^{3,15}$, Jeremiah Marsicek ${ }^{5}$, Jason McLachlan ${ }^{16}$, Cary J. Mock ${ }^{17}$, David J. P. Moore ${ }^{18}$, Jonathan Nichols ${ }^{19}$, Dorothy Peteet ${ }^{19}$, Kevin Schaefer $^{20}$, Valerie Trouet ${ }^{21}$, Charles Umbanhowar ${ }^{22}$, John W. Williams ${ }^{4}$, and Zicheng Yu ${ }^{6}$

${ }^{1}$ Yale School of Forestry and Environmental Studies, New Haven, CT 06511, USA

${ }^{2}$ Harvard Forest, Harvard University, Petersham, MA 01366, USA

${ }^{3}$ Department of Geosciences, University of Arizona, Tucson, AZ 85721, USA

${ }^{4}$ Department of Geography, Center for Climatic Research, University of Wisconsin-Madison, Madison, WI 53706, USA

${ }^{5}$ Department of Geology and Geophysics, University of Wyoming, Laramie, WY 82071, USA

${ }^{6}$ Earth and Environmental Science Department, Lehigh University, Bethlehem, PA 18015, USA

${ }^{7}$ Department of Geography, University of Oregon, Eugene, OR 97403, USA

${ }^{8}$ Department of Civil and Environmental Engineering and Earth Sciences, University of Notre Dame, Notre Dame, IN 46556, USA

${ }^{9}$ Division of Earth and Ecosystem Sciences, Desert Research Institute, Las Vegas, NV 89119, USA

${ }^{10}$ Tree-Ring Laboratory, Lamont-Doherty Earth Observatory, Palisades, NY 10964, USA

${ }^{11}$ School of Biology and Ecology, University of Maine, Orono, ME 04469, USA

${ }^{12}$ Department of Earth and Environment, Boston University, Boston, MA 02215, USA

${ }^{13}$ Department of Geology and Geography, West Virginia University, Morgantown, WV 26501, USA

${ }^{14}$ Department of Geological Sciences, Salem State University, Salem, MA 01970, USA

${ }^{15}$ Southwest Climate Science Center, US Geological Survey, Tucson, AZ 85719, USA

${ }^{16}$ Department of Biological Sciences, University of Notre Dame, Notre Dame, IN 46556, USA

${ }^{17}$ Department of Geography, University of South Carolina, Columbia, SC 29208, USA

${ }^{18}$ Department of Geosciences and School of Natural Resources and Environment, University of Arizona, Tucson, AZ 85721, USA

${ }^{19}$ Biology and Paleo Environment, Lamont-Doherty Earth Observatory, Palisades, NY 10964, USA

${ }^{20}$ National Snow and Ice Data Center, University of Colorado, Boulder, CO 80309, USA

${ }^{21}$ Laboratory of Tree-Ring Research, University of Arizona, Tucson, AZ 85721, USA

${ }^{22}$ Departments of Biology and Environmental Studies, St. Olaf College, Northfield, MN 55057, USA

Correspondence to: Jennifer R. Marlon (jennifer.marlon@yale.edu)

Received: 13 October 2016 - Discussion started: 2 November 2016

Revised: 24 June 2017 - Accepted: 2 August 2017 - Published: 13 October 2017 
Abstract. Many ecosystem processes that influence Earth system feedbacks - vegetation growth, water and nutrient cycling, disturbance regimes - are strongly influenced by multidecadal- to millennial-scale climate variations that cannot be directly observed. Paleoclimate records provide information about these variations, forming the basis of our understanding and modeling of them. Fossil pollen records are abundant in the NE US, but cannot simultaneously provide information about paleoclimate and past vegetation in a modeling context because this leads to circular logic. If pollen data are used to constrain past vegetation changes, then the remaining paleoclimate archives in the northeastern US (NE US) are quite limited. Nonetheless, a growing number of diverse reconstructions have been developed but have not yet been examined together. Here we conduct a systematic review, assessment, and comparison of paleotemperature and paleohydrological proxies from the NE US for the last 3000 years. Regional temperature reconstructions (primarily summer) show a long-term cooling trend (1000 BCE-1700 CE) consistent with hemispheric-scale reconstructions, while hydroclimate data show gradually wetter conditions through the present day. Multiple proxies suggest that a prolonged, widespread drought occurred between 550 and $750 \mathrm{CE}$. Dry conditions are also evident during the Medieval Climate Anomaly, which was warmer and drier than the Little Ice Age and drier than today. There is some evidence for an acceleration of the longer-term wetting trend in the NE US during the past century; coupled with an abrupt shift from decreasing to increasing temperatures in the past century, these changes could have wide-ranging implications for species distributions, ecosystem dynamics, and extreme weather events. More work is needed to gather paleoclimate data in the NE US to make inter-proxy comparisons and to improve estimates of uncertainty in reconstructions.

\section{Introduction}

Many dimensions of climate - from gradual shifts in temperature and precipitation, to changing seasonal patterns, to extreme weather - influence species and ecosystem processes. An ecologically relevant understanding of regional climate variability thus requires diverse records that overlap in space and time. Such an understanding would enable the investigation of long-term ecosystem processes, such as succession, large-scale shifts in species composition, and periodic, infrequent disturbances like droughts and flooding, using models or empirical approaches.

In the northeastern United States (NE US) from the Great Lakes to New England, there are few natural archives, such as ice sheets, caves, or corals, that provide long regional climate records. The last deglaciation, however, left thousands of lakes and bogs filled with sediments that have recorded local environmental changes. As a result, the NE US paleoclimate has primarily been inferred from local studies and vegetation studies or from broad-scale syntheses that interpolate or downscale data to finer scales.

Temperature changes in the NE US during the late Holocene are generally inferred from global, Northern Hemisphere, and North American research that draws on marine archives (Marcott et al., 2013), tree rings in adjacent regions (Esper et al., 2002; Mann et al., 2009; Trouet et al., 2013), and continental-scale pollen-based climate reconstructions (Viau et al., 2012; Trouet et al., 2013). Such data show declining temperatures during the past 3000 years (during the "neoglacial") until about $1700 \mathrm{CE}(250 \mathrm{cal}$ yr BP), when the current regional warming trend began. Sea surface temperature (SST) reconstructions from marine sediment near Nova Scotia also indicate consistently cooler-than-present conditions during the past 1500 years (Keigwin et al., 2003).

The extent to which broad temperature trends reflect regional, terrestrial climate in the NE US is unclear. Results are contradictory regarding changes during the Medieval Climate Anomaly (MCA; ca. 950-1250 CE; 1000700 cal yr BP) and the Little Ice Age (LIA; ca. 14001700 CE; 550-250 cal yr BP; Mann et al., 2009). Warming during the MCA is not observed in SST reconstructions near Nova Scotia (Keigwin et al., 2003), and ecological studies have shown complex responses to climate changes during this interval (Fuller et al., 1998; Umbanhowar, 2004). Vegetation-based climate reconstructions suggest relatively high temperatures during the MCA in the deciduous and hardwood forests of eastern North America about 1300 years ago (Viau et al., 2012) and about 1000 years ago (Trouet et al., 2013), respectively. LIA cooling registers strongly in vegetation and fire regimes in both the Midwest and NE (Umbanhowar, 2004; Clifford and Booth, 2013). Vegetation is controlled by many factors in addition to climate, however, and would ideally be reserved to evaluate the ecological responses to the climate history rather than used for both climate and ecological reconstruction, especially in a modeling context.

Data reflecting hydroclimatic variability are more abundant in the NE US, coming from tree-rings (e.g., Cook and Krusic, 2004, 2008; Pederson et al., 2014), lake levels (e.g., Shuman et al., 2002), variations in lake chemistry (e.g., Li et al., 2007), shifts in diatoms (Boeff et al., 2016), and changes in testate amoeba composition from bog sediments (e.g., Booth et al., 2012). Such data show relatively wet conditions in the late versus the mid-Holocene (Digerfeldt et al., 1992; Almquist et al., 2001; Shuman et al., 2009) with increasing effective moisture towards present (Newby et al., 2014). Episodic drought and pluvial events, documented by a variety of proxies, are superimposed on the gradual trend towards increasing moisture (Pederson et al., 2005). The synchroneity of such events is largely unexplored.

To provide a new perspective on regional, terrestrial climate changes in the NE US (Peterson et al., 2013), we examine local and regional paleoclimate data from the NE US, defined here as $100-60^{\circ} \mathrm{E}$ and $38-52^{\circ} \mathrm{N}$ (Fig. 1). Our objec- 
tives are to (1) identify the data resources of the region to help prioritize and motivate new data collection; (2) improve our understanding of regional climate evolution over centuries and millennia; and (3) enhance our ability to contextualize current and projected environmental changes. To these ends, we first review the strengths and limitations of different kinds of paleoclimatic proxies and archives. We then discuss uncertainties in paleoclimate reconstructions, an issue fundamental for advancing climate and ecosystem modeling. Finally, we compare and contrast the diverse NE US datasets to assess past trends in temperature and moisture availability and to identify shared features and inconsistencies in centennialscale events.

\section{Review of existing NE US paleoclimate records}

Here we describe the most common paleoclimatic data sources (proxies) and the natural archives containing them in the NE US. Natural archives result from complex flows of materials, energy, and water through the landscape (Fig. 2). As a result, they incorporate many processes unrelated to climate. Removing non-climatic signals is thus a major challenge for studying paleoenvironmental change.

Identifying records from a variety of proxies is important because different sources often reflect unique aspects of climate change. Lake level records and diatom-based records of past salinity integrate the temperature $(T)$, precipitation $(P)$, and evapotranspiration (ET) variations sensed by bogs with groundwater inputs $(Q)$ operating over timescales of decades to centuries. The sensitivity of lake hydrology to climate variability depends heavily on lake size, volume, shape, position in watershed, and degree of connectivity to subsurface water flows. Terrestrial ecological systems are governed by climatic variability and ecological responses to this variability at timescales of years to centuries and at levels of ecological organization ranging from individual organisms to communities and ecosystems. Proxies obtained from tree rings sense the growth responses of individual trees at timescales of seasons to decades, while the biomarker, isotopic, and pollen signals recorded in bog and lake archives are typically time-averaged by depositional processes, with the degree of time-averaging varying among archives. The proxies found in marine archives are mostly produced by marine organisms (e.g., biomarkers) but some, such as pollen, are terrestrially sourced (Fig. 2).

Each natural archive is associated with a typical record length (Fig. 3), which in turn constrains the timescales of climate variability that can be reconstructed (e.g., hourly, seasonal, decadal, millennial). Longer records tend to have lower temporal resolution due to sampling constraints. The diversity of climatic and non-climatic signals that register in a proxy, along with the differences in record lengths and spatial coverage, makes it difficult to compare records and presents a key challenge for building robust paleoclimate re- constructions. Few proxies can capture multidecadal temperature or moisture variability with high temporal resolution. Tree-ring records, for example, are the only non-instrumental data source in the NE that can consistently capture seasonal or annual variations (Fig. 3). Nonetheless, an assessment of the existing data in the NE US highlights opportunities for bridging multiple scales of variability, such as paired records from nearby bogs and lakes, or composite records from regional tree-ring reconstructions.

\subsection{Modern and historical climate records}

Observations and measurements of weather and climate during the modern (1950-present) and historical (1600 $1950 \mathrm{CE})$ periods in the NE US provide accurate, comprehensive information about recent climate changes. Hourly temperature and precipitation measurements, relative humidity, wind speed and direction, and barometric pressure are measured at various elevations. Other variables, such as soil moisture, can be calculated. Hourly or daily data can be aggregated seasonally, annually, and decadally to examine short-term variability. In addition to documenting ongoing climate changes, such data support modeling future changes (Hayhoe et al., 2007) and the calibration of paleoclimate records.

The United States Historical Climatological Network (USHCN), which includes hundreds of US weather stations that are often still in operation today (http://www. ncdc.noaa.gov/oa/climate/research/ushcn/), provides continuous climate data spanning the past century or more through to present. Historical data from forts and voluntary citizen observers stored in the National Archives and Records Administration (http://mrcc.sws.uiuc.edu/FORTS/ inventory1.jsp) extend back to the 19th century in some cases. Some of these stations became part of the USHCN, thereby providing a continuous record of climate from the historical period through the present (Tipton et al., 2016). Hiatuses are common in the fort data, however, and measurements were not taken at the same time of day at different stations, so uncertainty is generally higher than in the USCHN data.

A variety of other historical climate records are used to reconstruct particular weather events, such as storms and hurricanes (Mock, 2012). Documentary archives generally span decades or a few hundred years and come from early instrumental records, personal diaries, newspapers, and ship logs. Such records can be very accurately dated and detailed, but spatial coverage is limited and uncertainties tend to increase with record length. Other sources of historical data come from careful, systematic observations of environmental changes like ice-out dates (Hodgkins, 2013), changes in the timing of seasons or precipitation patterns, and changes in lake levels or phenology (e.g., arrival date of particular migrating bird species or the blossom dates of certain plant species; Primack et al., 2004). 

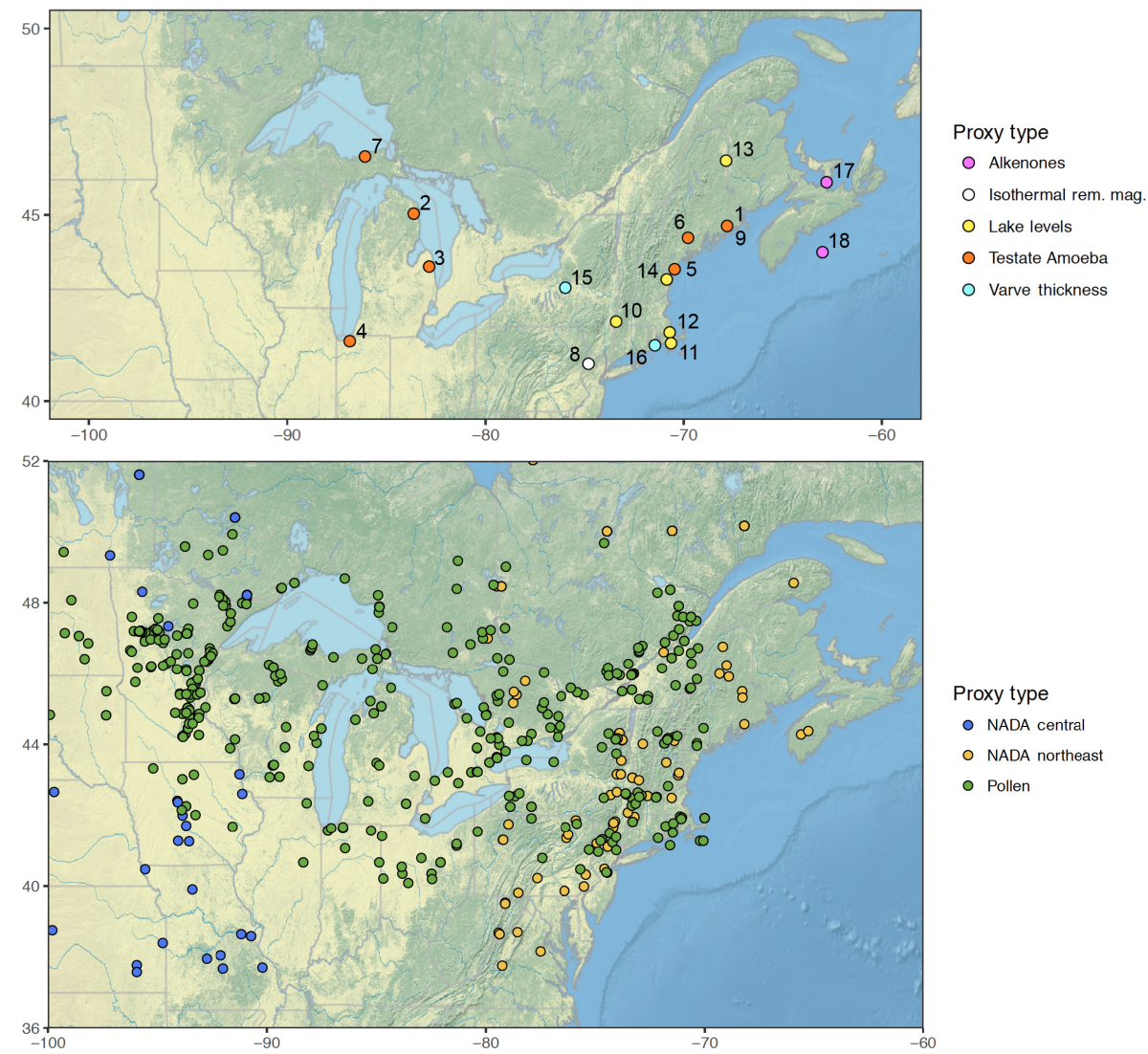

Figure 1. Locations of sites (see Table 1 for upper panel site index) with paleoclimate data used in this paper that span at least 2 centuries reconstructed from various sources in the northeastern US. Isothermal rem. mag. is isothermal remanent magnetization; NADA is the North American Drought Atlas.

Modern and historical data show annual temperatures in the NE US increasing by almost $1.1^{\circ} \mathrm{C}$ and precipitation increasing by about $12 \mathrm{~cm}$ (more than $10 \%$ ) over the past century (Horton et al., 2014). Precipitation timing is also changing, with the heaviest events from 1958-2012 increasing $37 \%$ in the Midwest and $71 \%$ in the Northeast (Karl, 2009). The frequency of daily summer precipitation (June, July, August) has significantly increased since the mid-1990s in the Ohio Valley of Ohio and Kentucky and in eastern New York state (Bishop and Pederson, 2015). Seasonal changes are also evident, with warming strongest in winter and precipitation increases most pronounced in the fall (Kunkel et al., 2013). Loss of winter ice cover on Lake Superior has caused the summer surface water temperatures there to increase approximately $2.5^{\circ} \mathrm{C}$ between 1979 and 2006 (Austin and Colman, 2007). In Maine, ice-out dates (the dates when lake ice first breaks up each spring) are getting earlier, reflecting warming over the past century (by 0.6 days decade ${ }^{-1}$ from 1884 through 2008; Hodgkins, 2013). Sebago Lake in Maine has been failing to freeze completely at an increasing rate since 1937, and projections for continued warming signal significant ecological and economic impacts in the region through its effects on fisheries, transportation (e.g., snowmobile trails) recreation, and other resources. Warming thus appears to be more rapid in southern than northern New England thus far, but upwards trends in both temperatures and precipitation are expected to continue in coming decades (Anderson et al., 2010).

\subsection{Tree-ring records}

Tree-ring records provide the most abundant data about seasonal to decadal drought and temperature variations beyond the historical record (Speer, 2010). Records from long-lived species like bristlecone pine (Pinus longaeva) or bald cypress (Taxodium distichum), neither of which grow in this region, are used to extend instrumental records of climate back 1000-3000 years or more in some cases, but limited tree longevity and preservation of samples for cross-dating often limit longer-term analyses. Using ring widths, wood density, or stable isotopic content, dendroclimatic (tree-ring-based paleoclimate) reconstructions of temperature and moisture availability can be created from a network of tree-ring records. In addition, growth suppression (Trouet et al., 2016) and tree-ring anatomical variability (Therrell and Bialecki, 
Table 1. Site ID, location, data type, sample resolution for the past 3000 years, and citations for sites used in this study. IRM is isothermal remanent magnetization and SVR is Sphagnum/ vascular ratio. The sample resolution for New Long Pond could not be obtained as raw data were not provided for the study. Mathews Pond and Whitehead Lake are not provided because a continuous age model was not constructed and trends are therefore approximations only.

\begin{tabular}{|c|c|c|c|c|c|c|}
\hline ID & Site name & Type & Lat. & Long. & Avg. yrs/sample & Citation \\
\hline 1. & Great Heath Bog, ME & Testate amoeba & 44.70 & -67.81 & 11 & Clifford and Booth (2013) \\
\hline 2. & Irwin Smith Bog, MI & Testate amoeba & 45.03 & -83.62 & 49 & Booth et al. (2012) \\
\hline 3. & Minden Bog, MI & Testate amoeba & 43.62 & -82.84 & 16 & Booth et al. (2003) \\
\hline 4. & Pinhook Bog, IN & Testate amoeba & 41.61 & -86.85 & 21 & Booth et al. (2012) \\
\hline 5. & Saco Bog, ME & Testate amoeba & 43.55 & -70.46 & 5 & Clifford and Booth (2013) \\
\hline 6. & Sidney Bog, ME & Testate amoeba & 44.39 & -69.78 & 18 & Clifford and Booth (2013) \\
\hline 7. & South Rhody Bog, MI & Testate amoeba & 46.56 & -86.07 & 27 & Booth et al. (2012) \\
\hline 8. & White Lake, NJ & IRM & 41.00 & -74.80 & 98 & Li et al. (2007) \\
\hline 9. & Great Heath Bog, ME & SVR & 44.70 & -67.81 & 14 & Nichols and Huang (2012) \\
\hline 10. & Davis Pond, MA & Lake level & 42.14 & -73.40 & 1.85 & Newby et al. (2014) \\
\hline 11. & Deep Pond, MA & Lake level & 41.56 & -70.64 & 1.85 & Marsicek et al. (2013) \\
\hline 12. & New Long Pond, MA & Lake level & 41.85 & -70.71 & 1.85 & Newby et al. (2014) \\
\hline 13. & Mathews Pond, ME & Lake level & 43.27 & -70.86 & Not available & Dieffenbacher-Krall (2005) \\
\hline 14. & Whitehead Lake, ME & Lake level & 46.46 & -67.86 & Not available & Dieffenbacher-Krall 2005 \\
\hline 15. & Green Lake, NY & Varves & 43.05 & -75.97 & 1 & Hubeny et al. (2014) \\
\hline 16. & Pettaquamscutt R. Estuary, RI & Varves & 41.50 & -71.45 & 1 & Hubeny et al. (2014) \\
\hline 17. & Emerald Basin & Alkenones & 45.89 & -62.80 & 39 & Keigwin et al. (2011) \\
\hline 18. & Scotian Margin & Alkenones & 44.00 & -63.00 & 72 & Sachs et al. (2007) \\
\hline
\end{tabular}

2015) can be used to reconstruct extreme events, such as hurricanes and floods.

Specific extreme climatic events or decadal climate fluctuations can be identified using dendroclimatology, which relies on precise and accurate dating of each ring (Black et al., 2016); this is a non-trivial exercise, particularly in closed canopy forests where many factors influence growth. Treering reconstructions also employ direct calibration and verification of the climate-growth model from instrumental data. Rigorous statistical testing of these models builds confidence that reconstructions of historical climate represent an approximation of the range of past variation, or at least of variations in surviving trees. As with many paleoclimate proxies, reconstructions from tree rings are generally biased towards the growing season because dormant season (winter) changes have much less of an affect on radial growth. In addition, climate changes in spring versus fall, for example, may affect rings differently; fall climate primarily affects growth in the following year. Dendroclimatology methods are reviewed in detail in Cook and Kairiukstis (1990). Key limitations of tree-ring records of past climate are predicated on tree longevity, the ability to retain low-frequency trends, and the geometric and ecological factors influencing stem growth (Fritts, 1976; Cook and Peters, 1997).

In the NE US, tree-ring records are limited in length, rarely extending beyond the past 500 years. Growth is influenced by non-climatic and climatic factors (Cook and Pederson, 2011), and most NE US trees are moisture- rather than temperature-sensitive (Stahle and Hehr, 1984; Cook, 1991; Meko et al., 1993). Conifers at high elevations or northern range margins have the strongest significant and positive relationships to temperature (Conkey, 1982; Pederson et al., 2004; Bhuta et al., 2009), and the temperature sensitivity of red spruce wood density (Conkey, 1986) and Atlantic whitecedar ring widths (Hopton and Pederson, 2005) in particular have produced reliable reconstructions. Red spruce sensitivity to acid rain, however, may complicate the most recent temperature reconstructions (Webster et al., 2004).

In the NE US, only a few tree species in a specific portion of their range are sensitive enough for temperature reconstructions (Conkey, 1986; Pederson et al., 2004; Hopton and Pederson, 2005). Several records of 1000 years or longer are solely from cliff-dwelling northern white cedar or eastern red cedar and account for a lower proportion of annual variance in the instrumental record versus most other reconstructions. Such limitations can be overcome by combining multiple species (Cook and Pederson, 2011; Maxwell et al., 2011; Pederson et al., 2013), but this limits the robustness of longer reconstructions.

The most common paleoclimatic reconstruction target from tree rings is the Palmer Drought Severity Index (PDSI), especially in the NE US due to the limited temperature sensitivity of most species. The PDSI is not directly measured but is rather modeled using precipitation and temperature, soil types, and solar radiation varying by latitude. The North American Drought Atlas (NADA; Cook and Krusic, 2004; Cook et al., 2004) provided new insights into broad-scale hydroclimate variations. Most early NADA research focused on the great droughts of the western US and Great Plains (e.g., Fye et al., 2003; Cook et al., 2004; Stahle et al., 2007), but 


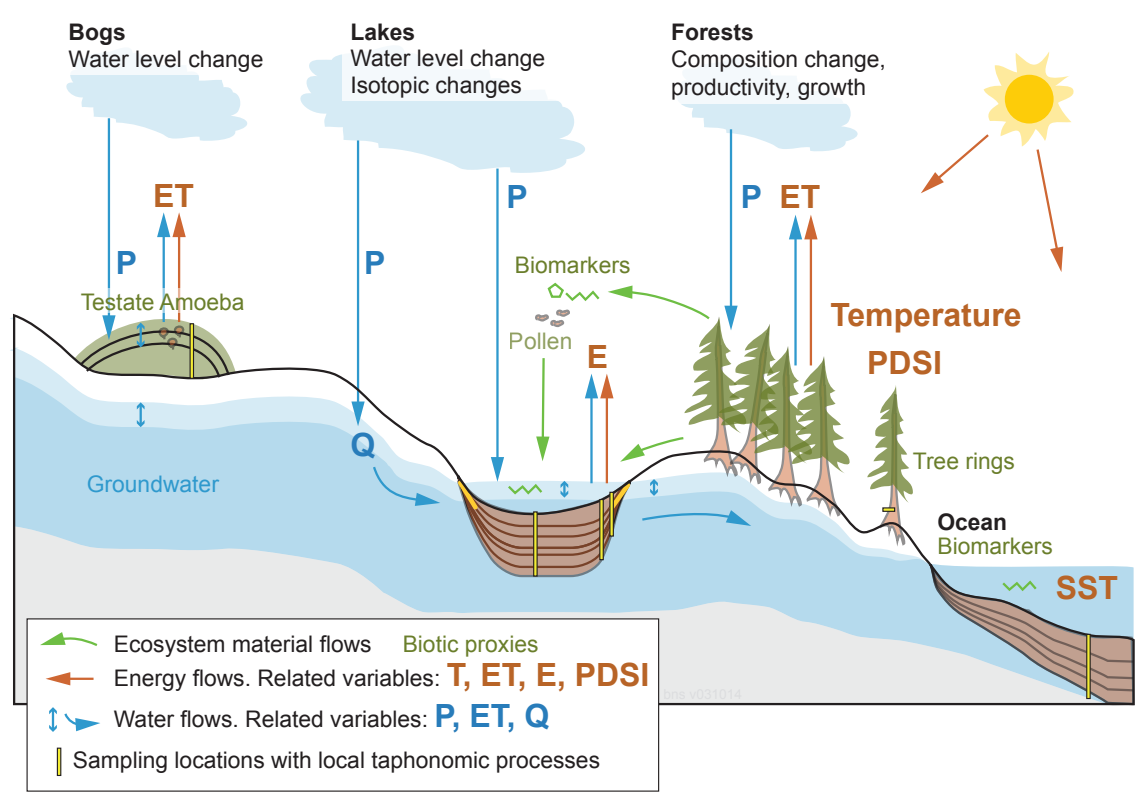

Figure 2. Natural archives, such as sediments, bogs, and trees rings, capture signatures of energy, water, and other material flows between the biosphere, surface hydrosphere, and atmosphere. Paleoclimate proxies are the various biological, geochemical, and physical characteristics of these archives that are influenced by climatic variations. Ombrotrophic bogs are perched above the water table and thus they and their testate amoebae assemblages are not affected by groundwater flows $(Q)$. Rather, the composition of testate amoebae assemblages within bogs is governed by the differential sensitivity of testate amoebae species to the height of the water table within the bog, governed by the balance between precipitation $(P)$ and evapotranspiration $(\mathrm{ET})$, which is in turn affected by temperature $(T)$. Lake level records and diatom-based records of past salinity integrate decadal- to century-scale $T, P$, and evaporation $(E)$ variations. Tree-ring growth responds to seasonal $T$ and $P$ variations and is often used to reconstruct the Palmer Drought Severity Index (PDSI). Biomarker, isotopic, pollen, and macrofossil signals recorded in bog and lake archives capture decadal or longer-term processes due to processes that affect particle transportation and deposition. The proxies found in marine archives are mostly produced by marine organisms (e.g., biomarkers) but some, such as pollen, are terrestrially sourced.

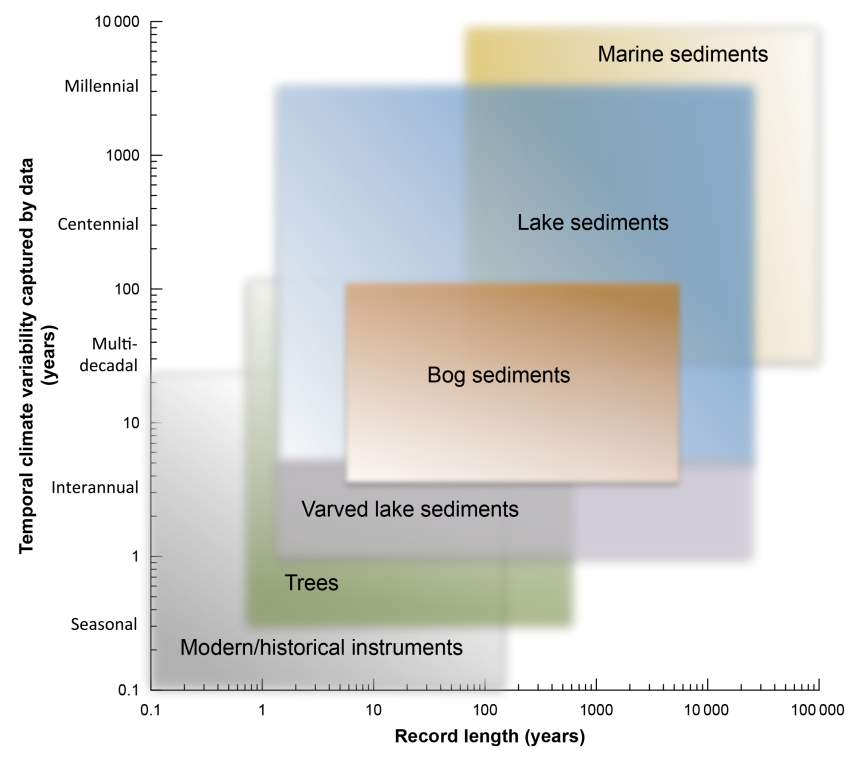

Figure 3. Temporal climate variability captured and typical record lengths characteristic of paleoclimate data available in the NE US. within the last decade, a focus on NE US hydroclimate has emerged. In the central Mississippi River Valley, a summer PDSI reconstruction shows a sustained wetting trend from the 1100-1247 CE dry epoch through present day (Cook et al., 2010). Analysis of tree rings from the Red River indicate an extended dry period from 1675 to $1770 \mathrm{CE}$ (George and Nielsen, 2002). Summer moisture across the central portion of the eastern US has been increasing since at least the early 1800s (McEwan et al., 2011). Similar trends are evident from PDSI reconstructions in eastern NY state and western New England, with a general reduction in the severity and duration of drought in the 20th century versus the prior 350 years (Pederson et al., 2013). At the northern end of the Mississippi River in Minnesota, Iowa, and Wisconsin, summer PDSI over the last 500 years also indicates a general wetting trend (Pederson et al., 2015).

At annual to decadal timescales, properly dated tree-ring records of past climate demonstrate how climate affects ecological and societal dynamics (Stahle et al., 1998; Cook et al., 2010). Both qualitative and quantitative tree-ring data have been used to understand how intensive drought contributed to the severe mortality rates among the first European settlers in Jamestown, for example (Stahle et al., 1998), and how 
paleoclimate variations can affect ecosystem services today (Pederson et al., 2015).

\subsection{Bog records}

Analyses of peatland sediment from bogs have been widely used in North America and Europe to provide information about changes in vegetation communities and fire regimes from fossil pollen, macrofossils, and charcoal. Bog sediments from ombrotrophic bogs, or raised bogs, are also a unique source of hydroclimate data because precipitation is their sole moisture input, which affects water table depth (WTD). WTD changes, in turn, affect the composition of testate amoebae communities - a group of protists that produce decay-resistant shells - in the bog. Different species of testate amoebae have different sensitivities to moisture, so measuring changes in their relative taxa abundances or community assemblages over time enables the reconstruction of past changes in WTD and thus hydroclimate near the bog (Booth et al., 2002; Booth, 2008; Mitchell et al., 2008).

Bog surface moisture responds predominantly to growing season precipitation (Booth et al., 2010; Charman et al., 2004; Charman and Blundell, 2007; Charman et al., 2009). In the NE US, bog data most closely reflect the length and severity of the summer moisture deficit, which is usually related to summer precipitation (Charman and Blundell, 2007; Booth, 2010). There can be important differences in seasonal sensitivities, however, across both space and time, and the relative importance of precipitation versus temperature can also vary among sites (Booth, 2010). Thus in some cases, changes in WTD may be more closely correlated with summer PDSI, while elsewhere it may better reflect annual PDSI. Still other bogs may respond to temperature more than precipitation variations, which may be correlated with each other and thus produce effects that are very difficult to disentangle.

For WTD reconstructions, an empirical (e.g., weightedaverage) model is developed from a modern calibration dataset and is used to infer temporal changes in WTD from downcore compositional changes (Booth, 2008). Calibration datasets for modern testate amoeba are based on samples collected along moisture gradients in the bog, however, which means that reconstructions of absolute precipitation values is not possible. As a result, inferred WTD changes at a coring location reflect relative rather than absolute changes in surface moisture through time. Additional analyses are typically used to evaluate the robustness of the paleohydrological reconstruction. It is common to compare the WTD reconstructions to peat humification data from the same core, for example, and to compare records among bogs from the same region. Such comparisons provide an assessment of both the robustness of the paleohydrological reconstruction and its climatic sensitivity. Booth (2010) showed that WTD reconstructions were strongly correlated with PDSI, as were downcore comparisons with hydrologic and climatic data (Booth et al., 2010).
Modeling studies suggest that extreme events register strongly in bog records (Morris et al., 2015; Clifford and Booth, 2015), whereas lower-magnitude and lowerfrequency changes in WTD may be more strongly influenced by autogenic processes such as lateral peat-bog expansion, vertical peat growth, decomposition-induced changes in hydraulic conductivity, and other ecological dynamics (Charman et al., 2006; Swindles et al., 2012; Morris et al., 2015). As in dendroclimatic reconstructions, detrending WTD data removes potential non-climatic signals but concurrently limits paleoclimate inferences to extreme centennial to multidecadal events (Charman et al., 2006; Booth et al., 2012).

In eastern North America, the best-dated sites are from Michigan and Maine (Booth et al., 2012; Clifford and Booth, 2013). Drought, vegetation, and fire reconstructions from several New England records reveal an abrupt decline in eastern hemlock (Tsuga canadensis) and American beech ( $\mathrm{Fa}$ gus grandifolia) concomitant with an increase in pine ( $P i$ nus spp.) and oak (Quercus spp.) between 1350 and $1450 \mathrm{CE}$ (500 and $600 \mathrm{yr}$ BP) from increased drought and fire (Clifford and Booth, 2013).

\subsection{Lake and marine records}

Lake and marine sediments can capture long (multidecadalto millennial-scale) variations in climate, and several methods used to study paleoclimate in sediments can be applied to both lake and marine sediments, including fossil pollen and macrofossils, and approaches based on organic geochemistry. Lake and marine sediments are commonly analyzed for a broad range of environmental data, some of which have paleoclimate information. Many of these data sources, however, are too complex to provide consistent, reliable data from a variety of sites. Grain size analyses, magnetic susceptibility, and loss-on-ignition, for example, are commonly quantified in sediments but often provide information that is ambiguous in terms of its climate signal and must be paired with other information. Site selection for lakes is critically important in providing conditions that are suitable for paleoclimatic reconstruction.

Important differences exist in reconstructions from marine versus lacustrine sediments. Different organisms and depositional contexts affect the kinds of variables that can be reconstructed, as well as the typical record lengths (marine records are longer), the typical temporal and spatial resolution (more coarse for marine sediments), and the amount of uncertainty in the dating. The number and nature of adjustments in the radiocarbon dating of sediments also varies in lake versus marine sediments. In addition, influences from non-climatic factors differ between lake and marine records. Sediment deposition is affected by oceanic currents in marine contexts, and from inflowing and outflowing streams or from groundwater flow in a lake basin. 


\subsubsection{Annually laminated sediments (varves)}

In some lakes, annual sediment accumulations form distinct annual layers, called varves, that are often visible as thin, differently colored bands. This typically occurs in small lake basins with steep slopes and limited wind-driven currents that prevent seasonal mixing of surface and bottom waters. In this case, the deep benthos is unventilated and hence permanently anoxic, preventing organisms that normally exist in the sediment from disturbing the layering. Varved lakes are rare, but they can yield unusually detailed information about annual and sometimes seasonal variations in environmental conditions over millennia.

Paleoclimate information from varved lakes has generally come from the interpretation of changes in vegetation composition from fossil pollen (described below; Gajewski, 1987). A varved sediment record from Elk Lake, Minnesota shows that white pine (Pinus strobus) largely replaced oak savanna about 750 BCE (2700 cal yr BP; Bradbury, 1996), for example. Variations in the thickness of varves themselves can also provide climate information. Varve thicknesses from Elk Lake, Minnesota were linked to solar activity and wind intensity during the early and mid-Holocene, but late-Holocene varve thicknesses were not easily explained (Bradbury, 1996). Pollen and charcoal data from Hell's Kitchen Lake in north-central Wisconsin indicated alternating moist and dry intervals over the past 2000 years but yielded no long-term trends in temperature or moisture (Swain, 1978). Data from Hubeny et al. (2011) show variations in varve thickness from two sites in New York and Rhode Island (Fig. 1a). Varve thickness variations in both records are positively correlated with hydroclimate indices that suggest broad-scale forcings of decadal- to centennialscale drought events.

\subsubsection{Lake level reconstructions}

Changing lake levels provide a clear and visual indication of changing climate conditions, specifically variations in moisture balance integrated over decades or longer. In the western US, for example, former strand lines of pluvial lakes Bonneville and Lahontan testify to wetter conditions in the distant past that are difficult to even imagine based on the modern climate (Fritz, 1996). In humid regions such as the NE US, such evidence may not be as visually obvious because high water now submerges ancient shorelines from past dry periods (Freeman-Lynde et al., 1980; Hutchinson et al., 1981; Mullins and Halfman, 2001). Shoreline features have long been used to reconstruct lake levels, but such information does not provide a continuous record of change.

More recently, lithologic and magnetic measurements made from sediments have been used to develop continuous reconstructions of past drought and periods of sustained aridity. Measurements of isothermal remanent magnetization (IRM) were used to produce a record of Holocene drought events (Li et al., 2007) from White Lake, New Jersey that are strongly correlated with cold events in the North Atlantic (Bond et al., 2001). The IRM records show large shifts in lake levels that represent discrete drought events, but gradual trends are not evident in the data; see Geiss et al. (2003). Strong magnetism in the sediments occurs when the sediment is comprised of marls (lime-rich sediment) rather than gyttja (organic-rich sediment). When the lake levels are reduced, the marls are exposed, oxidized, eroded, and transported to the deeper sediments of the lake, causing both a color change from brown to light yellow and a corresponding increase in magnetism (Li et al., 2007).

Sediment analyses that produce paleoclimatic records can often come from sites with unique hydrological or bathymetric characteristics that make them sensitive recorders of climate change but are not reproducible at other sites. The ridge top location, underlying quartz conglomerate, and thin soils of Mohonk and Minnewaska lakes, New York (Menking et al., 2012), for example, make these sites especially vulnerable to drought and thus sensitive recorders of hydroclimatic changes. Both lakes show dramatic shifts in lake level during the late Holocene through increased erosion into the basin during droughts, increased pollen and macrofossils of pitch pine, and shallow water aquatic macrofossils. Such records can clearly reflect local hydrological variations, but calibration data and other nearby proxies are lacking, making it difficult to quantify the climatic signals, understand spatial patterns, and evaluate uncertainty.

Several lake level reconstructions in the NE US are based on ground penetrating radar (GPR) and transects of multiple sediment cores from a lake margin (Newby et al., 2014; Pribyl and Shuman, 2014). This approach enables continuous reconstructions of shoreline advances and retreats through time that at least partly reflect changing hydroclimate (Digerfeldt, 1986). Factors such as isostasy and tectonics can influence large lakes (Balco et al., 1997, 1998) but operate on scales greater than the small ponds that have been used to reconstruct regional hydrologic changes (Newby et al., 2014). Groundwater flow directly controls the water levels in many small ponds and lakes (Almendinger, 1993; Winter, 1999), but annual changes in precipitation and evaporation have strong regional impacts (Weider and Boutt, 2010). Suitable lakes for lake level reconstructions are usually formed within surficially closed basins and are controlled by climatically sensitive, near-surface groundwater fluctuations within well-defined watersheds. In the NE US, such lakes are ubiquitous, and comparisons of multiple lakes can limit confounding variables (Newby et al., 2014). Moreover, because lake level reconstructions are based on the changes in physical properties of the sediments themselves (i.e., direct measurements of past shoreline locations), biological and geochemical processes do not complicate interpretations. Care must be taken to consider hydrologic complexities (Donovan et al., 2002; Smith et al., 2002; Steinman and Abbott, 2013), but multisite validation using lakes located high in their local 
watersheds and in different hydrologic settings can improve climatic interpretations (Newby et al., 2014).

Radiocarbon dating is the primary constraint on the temporal resolution of lake level reconstructions because multiple cores are needed from each lake, introducing additional uncertainties from sampling, dating, and calibration (Newby et al., 2014). As a result, lake level reconstructions typically identify centennial- to millennial-scale climatic variability, although sediment signals of decadal droughts, such as the 1960s drought in New England, have been detected and dated (Newby et al., 2009). In addition, because lake levels vary in response to continuous changes in precipitation and evaporation usually integrated over 1-5 years (Mason et al., 1994), sub-annual hydroclimatic variations cannot be directly inferred (Shuman and Donnelly, 2006).

Transects of sediment cores are used to identify shifts in sand-mud boundary locations at the margin of each lake's littoral zone (Digerfeldt et al., 1992). GPR or other geophysical datasets can confirm the geometry of such changes (Newby et al., 2009; Shuman et al., 2009). A transect of two or more sediment cores across the lake are taken based on the GPR results. The results are then used to identify boundary shifts from changes in sediment characteristics, which enable the reconstruction of lake level variations over time.

Each centimeter (or finer) of sediment in the lake cores is classified as organic-rich profundal or as sand-rich littoral based on loss-on-ignition, bulk density, or x-ray fluorescence (XRF); this information is then used iteratively in an algorithm that creates a continuous estimate of lake level through time (Pribyl and Shuman, 2014). Reconstructed lake level variations can be coupled with watershed size and related information to reconstruct estimates of effective moisture (Shuman et al., 2009; Newby et al., 2014) or the ratio of actual evapotranspiration to potential evapotranspiration. In central New England, records are now being constructed for the creation of time series of effective moisture at centennial timescales throughout the Holocene (Marsicek et al., 2013; Pribyl and Shuman, 2014).

Because lake level variations represent century-scale or longer-term fluctuations, these records are difficult to calibrate against modern observations. Modern calibration work has therefore tended to focus on understanding water depthsediment relationships rather than on the calibration of the reconstructed and observed precipitation minus evaporation $(P-E)$. Efforts to validate the reconstructions include comparisons between lake level changes and pollen-inferred moisture changes (Marsicek et al., 2013) as well as comparisons of the reconstructions from multiple nearby lakes (Newby et al., 2014). Plank and Shuman (2009) also digitized hundreds of aerial photos of lakes from the 1930s to examine how their levels changed relative to PDSI observations. Newby et al. (2009) identified a thin sand layer in the upper portion of a core from New Long Pond in Plymouth, Massachusetts that dated to the 1960s drought, which depressed the local water table by $>3 \mathrm{~m}$. The sand layer shared the characteristics of many large sand layers used to infer prehistoric changes in water level. It may be possible to quantify the magnitude of the drought from the sediment data and compare it with the water table observations in future research. Recent work in New England suggests that sustained drought may have occurred in the past despite limited changes in moisture availability in the more recent past (Newby et al., 2014).

\subsubsection{Organic geochemistry}

The geochemical composition of bulk organic matter in sediments has long been used for environmental reconstruction. A wide array of geochemical data can be gathered from this organic matter, including abundance information, elemental distributions, and stable isotope ratios. With an understanding of thermodynamics, fractionation of stable isotopes, and advances in instrumentation applications, uses of stable isotopes have continued to grow. In marine sediment archives, stable oxygen $\left(\delta^{18} \mathrm{O}\right)$ and carbon $\left(\delta^{13} \mathrm{C}\right)$ isotope compositions of carbonate fossilized foraminiferal tests are used to reconstruct SST and global ice volume (Ravelo and HillaireMarcel, 2007). Likewise, the $\delta^{18} \mathrm{O}$ and $\delta^{13} \mathrm{C}$ values of lacustrine material have been examined as a source of paleoclimate information (Leng and Marshall, 2004; Meyers, 2003). These geochemical analyses are routine in settings with excellent preservation, but archives that are degraded or represent mixed terrestrial and aquatic inputs (Castañeda et al., 2011) can have complicated signatures.

Organic molecules, compounds, or groups of compounds that can be linked to specific source organisms or groups of organisms are called biomarkers. These are often recovered in locations where other bulk proxies are not available (Castañeda et al., 2011). Because they are insoluble in water, often chemically inert with low volatility, and resistant to biodegradation, they are long-lived in the environment and well suited for studies of the past (Eglinton and Hamilton, 1967; Eglinton and Eglinton, 2008).

Two key biomarker proxies from aquatic settings are $\mathrm{U}^{\mathrm{K}}{ }_{37}$, based on the differing number of double bonds of alkenones from haptophyte algae (Brassell et al., 1986; Herbert, 2001; Prahl and Wakeham, 1987), and TEX 86 , based on the membrane lipid ring structures of Thaumarchaeota (Powers et al., 2004; Schouten et al., 2002). These biomarkers have been recently used for temperature reconstructions from lakes and oceans. Modern calibration studies and comparisons between these proxies, along with foraminiferal reconstructions, have revealed important differences in the seasonality (Pitcher et al., 2011) and depth of production of the organisms these proxies are based on (Karner et al., 2001).

Terrestrial plant leaf wax biomarkers have been used to produce a range of paleohydrological reconstructions using compound specific hydrogen isotope values $\left(\delta^{2} \mathrm{H}\right.$; Sachse et al., 2012). Derived from the surface coating on leaves, leaf wax compound-specific $\delta^{2} \mathrm{H}$ values demonstrate strong 
relationships with mean annual precipitation (Sachse et al., 2004), though new research suggests they reflect a more limited interval of time surrounding leaf development (Tipple et al., 2013). In the NE US, Nichols and Huang (2012) used the ratio of the $\mathrm{C}_{23} n$-alkane (representing bog-dwelling Sphagnum) to the $\mathrm{C}_{29}$ n-alkane (representing five drytolerant vascular plants) as an indicator of relatively wet versus dry conditions over the Holocene at a coastal bog in Maine. Hou et al. $(2006,2007)$ developed paleoclimate reconstructions from $\delta^{2} \mathrm{H}$ values of the aquatic lipid behenic acid $\left(\mathrm{C}_{22}\right.$ n-alkanoic acid) from a sediment core in Blood Pond, Massachusetts and showed that variations in local climate paralleled those observed in the $\delta^{18} \mathrm{O}$ variations from the Greenland Ice Sheet Project 2 (GISP2). Though the resolution is low for the last 3000 years, $\delta^{2} \mathrm{H}$ values of long chain terrestrial leaf wax compounds from Crooked and Berry ponds, Massachusetts suggest a wetting trend between 3 and 2 cal ka before becoming more dry and stable after 2 cal ka (Shuman and Donnelly, 2006). Several other Holocene climate reconstructions from the NE US have been developed from compound-specific $\delta^{2} \mathrm{H}$ in lake sediments (Hou et al., 2006; Huang et al., 2002), but these have primarily been used as corroborating evidence for large, abrupt climate changes during deglaciation, such as the $8.2 \mathrm{ka}$ event (Hou et al., 2007). As with other proxies, there are uncertainties, including the precise factors that influence lipid $\delta^{2} \mathrm{H}$ values (Sachse et al., 2012) and which specific organisms are responsible for generating the lipids used in $\mathrm{TEX}_{86}$ (Schouten et al., 2013). In general though, these approaches offer novel and promising ways to reconstruct both past hydrologic and temperature variability.

\subsubsection{Fossil pollen}

The most abundant paleodata in the NE US are pollen records developed from lakes, bogs, and other sediments that have been used primarily to understand changes in forest composition (Williams et al., 2004; Blois et al., 2011; Oswald and Foster, 2012; Marsicek et al., 2013). Through the use of transfer functions, pollen data have also been used to reconstruct paleoclimate (Webb et al., 1987, 1993; Viau et al., 2006; Bartlein et al., 2011; Viau et al., 2012).

Climate can be reconstructed from fossil pollen in sediment records because (a) the geographic distribution and abundance of plant species is strongly influenced by climatic factors such as temperature minima, temperature maxima, and water availability (Woodward, 1987) and (b) pollen abundances and distributions are a reliable, albeit biased, indicator of plant abundances and distributions (Webb, 1974; Solomon and Webb, 1985). Although pollen grains are typically identified only to the genus or family level rather than species level, higher taxa distributions are also determined by climate, and relationships can therefore be constructed between taxa assemblages and their locations in climate space (Bartlein et al., 2011). In the NE US, many species identifi- cations have been made from pollen data, which can refine the environmental interpretation (Lindbladh et al., 2003).

Spatially extensive surface (modern) pollen sample datasets are used to determine the contemporary relationships between climate and plant assemblages (Williams et al., 2006; Bartlein et al., 2011). Such training data are then used to establish empirical relationships between taxon abundance and selected climate variables. The unique relationships between specific taxa and climate, as determined by the analysis of the modern spatial datasets, are then applied to make paleoclimatic inferences from temporal variations in fossil samples. As with bogs, this space-for-time approach uses a variety of algorithms for transferring spatial climatepollen relationships to temporal pollen trends, such as modern analogue, constrained analogue, response surfaces, and transfer functions (Telford and Birks, 2009). Modern species distributions or process-based (inverse) modeling can also be used to predict vegetation composition, particularly in terms of plant functional types (Wu et al., 2007; Garreta et al., 2010). In the latter case, both species distributions and surface samples can be reserved for validation testing (Bartlein et al., 2011).

The use of fossil pollen records to reconstruct climate has a long history in eastern North America (Bartlein and Webb, 1985; Gajewski, 1988; Prentice et al., 1991; Webb et al., 1993, 1998; Jackson et al., 2000; Williams et al., 2000; Bartlein et al., 2011; Viau et al., 2012; Wahl et al., 2012). Pollen data have been used to reconstruct climate variables such as mean temperature of the coldest month, mean temperature of the warmest month, mean annual temperature, and mean annual precipitation and bioclimatic variables. Such reconstructions quantify the climate changes that have often been observed indirectly through the pollen-based vegetation reconstructions. Records from the prairie-forest ecotone in Minnesota, Iowa, Wisconsin, and farther west, for example, show rapid prairie expansion in the early Holocene and slower subsequent afforestation in response to wetter conditions (Williams et al., 2009). Widespread expansions of taxa adapted to cool, moist climates, like spruce and fir, are documented by pollen data from the late Holocene (Gajewski, 1987). Oak, which is drought tolerant and adapted to periodic disturbance, was reduced, and moisture-dependent chestnut (Castanea dentata) increased after ca. 1000 BCE (2950 cal yr BP) in New England (Davis, 1980; Shuman et al., 2004).

Short-term variations in plant assemblages associated with disturbance and succession are sometimes resolved in highresolution pollen records (Pederson et al., 2005), but more often centennial to millennial variations generally track climate changes with little lag time (i.e., less than 100 years) (Williams et al., 2002). An important constraint in using pollen data to reconstruct temperature variations exists when vegetation distributions may have been highly disturbed by human activity (e.g., agriculture). 
In addition to pollen, plant macrofossils (Birks and Birks, 2000) can provide a unique advantage in paleoclimate reconstruction because they add greater taxonomic and spatial precision than fossil pollen and can be utilized for precise AMS C-14 dating. Their usage predates pollen (Reid, 1899), and most add a species-specific component that is thus more precise than pollen (pollen is primarily identified to genus or family) for indications of temperature and precipitation. Conifer needles have been utilized to identify late-Holocene timing of specific treeline migration into both alpine (Jackson, 1989) and subarctic (Peteet, 1986) environments with paleoclimatic inferences. Additionally, aquatic macrofossils are often key indicators of lake level and can help to define both the hydroclimate and nutrient status as well as pH (Birks, 2002). Equally important for hydroclimate are bryophytes, which can often indicate both moisture and $\mathrm{pH}$ and are more sensitive to moisture than higher plants (Gignac, 2001).

An important caveat holds for the use of pollen and macrofossil data in climate reconstructions that are supporting modeling efforts. If these data are used to reconstruct vegetation changes in ecosystem models, then the same data cannot also be used to reconstruct the climate changes. Using the same data to drive both vegetation and climate change is circular reasoning because climate changes are expected to drive the vegetation changes in the first place.

\subsection{Diatoms}

Sediment diatoms provide hydroclimate information because different species have different salt tolerances, so community composition changes with shifts in lake salinity or temperature and/or stratification (Fritz et al., 2000; Rühland et al., 2015; Saros et al., 2012). As with most paleoclimate data sources, diatom community composition also responds to non-climate factors such as lake location and morphometry, which affect lake circulation, for example (Boeff et al., 2016; Wigdahl-Perry et al., 2016). Many of the space-fortime transfer functions used in pollen-based paleoclimatology have also been applied to diatoms (Juggins and Birks, 2012). Although diatoms have not been analyzed as often as pollen in the NE US, they offer a unique opportunity to disentangle environmental changes due to human activities from those of climate change (Battarbee et al., 2012). More comprehensive discussions of diatom responses to climate may be found in Saros et al. (2012), Saros and Anderson (2015), and Rühland et al. (2015).

\section{Uncertainty in paleoclimate reconstructions}

There are multiple sources of uncertainty in paleoclimate reconstructions stemming from both natural spatial and temporal variability as well as from our ability to understand, measure, and model environmental processes (Evans et al., 2013). Identifying, quantifying, and assessing the importance of different sources of uncertainty is a growing challenge in paleoclimate science as new proxies and models proliferate and new techniques for data-model assimilation place increasing importance on accurately quantifying uncertainty (Crucifix, 2012). The examination of uncertainty can occur through comparisons among different collections of observational evidence and between models and data. Providing quantitative estimates of uncertainty requires some kind of calibration or a comparison between the paleoreconstruction and an independent data source with known accuracy.

Uncertainty stems from two key sources of variability: (1) natural variability, which occurs through space and time in ecological and climatic processes that may be stochastic or systematic but are ultimately controlled by external factors; and (2) our knowledge of such changes, which can result from limitations or errors in observation, sampling, measurement, dating, analysis, and other sources (Goring et al., 2012; Tingley et al., 2012). Uncertainty can be examined qualitatively or quantitatively, and both approaches are common in paleoresearch.

In the ideal case, paleoclimate reconstructions are quantitatively calibrated using modern climate data. Comparisons of tree-ring reconstructions of PDSI against modern PDSI measurements, for example, show a moderately strong correlation $\left(R^{2}=0.55\right)$ in New York over the period in which they overlap, 1895-2000 CE (Fig. 4a). Such analyses allow for the calculation of error estimates for drought reconstructions for the preceding centuries (Pederson et al., 2013).

For paleoclimate reconstructions based on changes in biological community compositions like fossil pollen, diatoms, and testate amoeba, space-for-time calibration is needed before a paleoclimate reconstruction can be attempted. Annual precipitation reconstructed from modern pollen in lake sediments from eastern North America, for example, reconstructed using modern datasets and space-for-time calibration, compares well with observed annual precipitation $\left(R^{2}=0.70\right.$; Fig. 4b; Marsicek et al., 2013). For testate amoeba, Booth (2008) developed and tested a variety of transfer functions between community composition and water table depths. The spatial patterns in taxon distributions from eastern North America and the Rocky Mountains were compared against modern observations of water table depth at each site $\left(R^{2}=0.84 ;\right.$ Fig. $\left.4 \mathrm{c}\right)$. The resulting transfer functions were then applied to temporal variations in testate communities downcore. The accuracy of alternative transfer functions can be evaluated using cross validation, spatial leave-one-out approaches, and similar statistical methods. In a similar example from Booth (2010), water table depth (WTD) was reconstructed for Hole Bog (Booth, 2008), and the measurements were used to infer variations in past drought events. The correlation between WTD estimates and (averaged) instrumental PDSI values for 1895-2003 CE from the broader climate division $\left(R^{2}=0.39\right)$ helps assess but not partition the uncertainty (Fig. 4d). Bayesian approaches to calibration can help improve prediction skill (Tingley and 

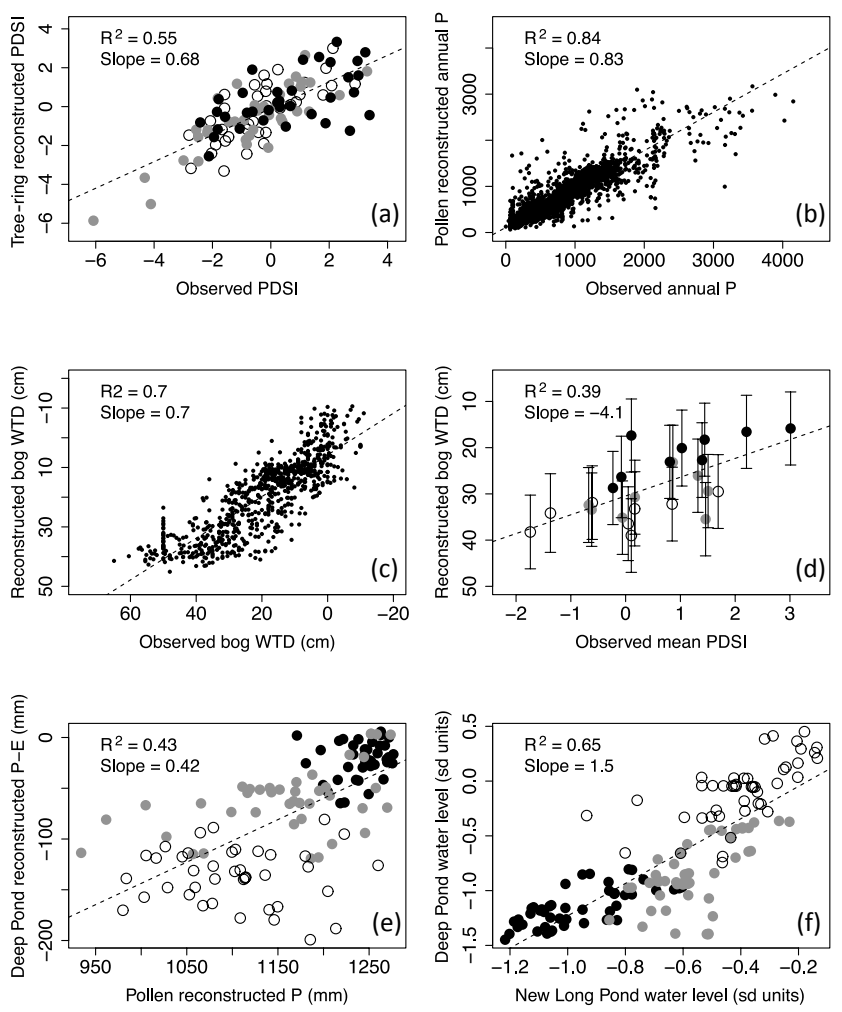

Figure 4. Calibration, internal validation, and multi-proxy comparison data for tree rings, pollen, lake levels, and bogs. (a) Instrumental (observed) versus reconstructed New York PDSI for 1895-2000 from tree rings; (b) observed versus reconstructed annual precipitation from pollen data (Marsicek et al., 2013); (c) observed versus reconstructed water table depth (WTD) from testate amoebae across North America (Booth, 2008); (d) Hole Bog, Minnesota WTD versus instrumental PDSI for 1895-2003 (which uses the mean PDSI for each of the sample intervals; Booth, 2008); (e) Deep Pond lakelevel-derived $P-E$ reconstruction versus the mean annual precipitation reconstruction based on the mean of multiple records in the region (Newby et al., 2014); (f) New Long Pond versus Deep Pond water elevations from southeastern MA for the past 7000 years (Newby et al., 2014). Comparisons in panels (e) and (f) include reconstruction error and temporal error because the two datasets in each case come from different sets of cores. For all plots, blackfilled dots are the oldest one-third, gray are the middle third, and unfilled are the youngest third. Note that panels (b) and (d) have declining axes.

Huybers, 2009) and may be applicable to other proxies, like pollen, that require transfer functions.

Many other types of sediment data contain paleoclimate information that cannot be directly calibrated, either because modern data for the variable measured do not exist or do not align closely enough with the temporal and/or spatial scale of the climate variability that is being reconstructed. In lake level reconstructions, for example, modern and historical precipitation records generally do not extend back far enough in time to allow validation of the centennial- and millennial- scale variations in the paleodata. In this case, inter-site and inter-proxy comparisons can still be used to increase confidence in the data. Lake level data, for example, along with information about watershed hydrology can be used to model variations in $P-E$ at a site, and these data can then be compared with a pollen-based precipitation reconstruction from the same site (Fig. 4e); at Deep Pond, Massachusetts, such a comparison yields an $R^{2}$ of 0.427 .

Alternatively, comparisons can be made between the same types of reconstructions from nearby sites. Two lake level reconstructions from Massachusetts (Fig. 4f) show a positive correlation of $0.654\left(R^{2}\right)$, providing convergent evidence that a given signal does indeed reflect climate changes and not other local processes. Such analyses can reduce uncertainty by allowing for assessments of relative changes over time; they can also serve as qualitative benchmarks for models. However, reducing uncertainty, whether through cross-site or cross-proxy comparisons, careful site selection, radiocarbon dating, or other methods, is insufficient to provide the quantitative estimates of uncertainty required for rigorously assimilating data into models.

To understand clearly whether differences in observed versus predicted data result from natural spatial or temporal variability in climate or from some aspect of the measurement process (e.g., differences in the locations of the proxies or in sampling error), process models can be developed. Process models are used to quantitatively identify, isolate, and measure the different sources of error in a reconstruction. Modeling the way in which a proxy registers climate information formally (Evans et al., 2013) opens new opportunities for integration with other proxies, hypothesis testing, and assimilation into more complex ecosystem models. Tipton et al. (2016), for example, developed a Bayesian hierarchical statistical model of tree-ring growth to jointly reconstruct temperature and precipitation at a site in the Hudson Valley, NY. Their multi-scale model allows tree growth to vary by species and to respond to both temperature and precipitation variations in climate through time at different temporal scales. Quantification of uncertainty at this level of rigor is only possible when calibration data are available for the appropriate spatial and temporal domain of a reconstruction. Even here, however, the accuracy of the reconstructions cannot always be fully constrained or quantified because of the myriad factors that influence an observational record.

\section{Coherence of NE US climate change records}

\subsection{Methods}

To assess the coherence of climate changes among the diverse paleoclimate records in the NE US (Fig. 1), we smoothed high-resolution records and composited and smoothed hundreds of tree-ring records from the North American Drought Atlas (NADA; Cook et al., 2010) and pollen records in the NE US (Williams et al., 2011) from 
the Neotoma Paleoecology Database (http://neotomadb.org). We identified drought events in the testate amoeba records and calculated sums of drought events to make this proxy comparable to gradual changes in lake levels and other hydroclimatic data.

High-resolution records, including the tree-ring-based temperature reconstruction from Esper et al. (2002), the composite varve thickness record from Hubeny et al. (2011), and the pollen-based temperature and precipitation records, were smoothed using the same approach. The data were first binned into 5-year time steps for all but the pollen data, which were binned into 10-year intervals due to their lower average temporal resolution. The binned data were then smoothed with a 50-year half-window width using locally weighted regression robust to outliers (Loader, 2007), except for the pollen data, which were smoothed with a 100year half-window width. The window widths were chosen to optimize the identification of both trends and shared major features in the records on centennial to millennial timescales. Bootstrap confidence intervals were created by sampling the sites in the full group with replacement for 1000 iterations.

For the pollen data (Fig. 1), the modern analogue technique was used to reconstruct climate variables (Williams et al., 2011). In this analysis, the climate variables were converted to anomalies so that shared patterns could be observed regardless of differences in the absolute values across the NE broadly. Pollen records were compiled from sites between 40 and $50^{\circ}$ latitude and -70 and $-100^{\circ}$ longitude (Fig. 1). The pollen data were not adjusted for human impact, so both the Williams et al. (2011) and Viau et al. (2006) records were clipped at $1850 \mathrm{CE}$.

Seven testate amoeba records (Booth et al., 2012; Clifford and Booth, 2013) were decomposed into low- and highfrequency components so that reconstructed drought events could be separated from trends in water table depth that may not be related to climate changes. The bog records were detrended again using locally weighted regression (Loader, 2007) with a 500-year half window. Droughts were identified in the detrended series as peaks above the 90th percentile. Identified drought events were then summed across all series to construct a regional summary index.

The tree-ring data (Fig. 1) from NADA (Cook et al., 2010) were used to calculate the drought area index (DAI) for the north-central and eastern portions of the NE. Grid cells included in the north-central region are from -100 to $-90^{\circ}$ longitude and 37.5 to $52.5^{\circ}$ latitude, and from 37.5 to $47.5^{\circ}$ latitude and -80 to $-65^{\circ}$ longitude for the eastern region. Data in each subregion (the Midwest and the North Atlantic Coast) were smoothed using methods from Cook et al. (2004).

To characterize the broad-scale spatial and temporal trends in temperature from the last century across the NE US, we analyze data from the Global Historical Climatological Network (GHCN) using empirical orthogonal functions (EOFs).
We also use EOF analysis to identify the spatial structure in the NADA from 1700-2005.

Two reconstructions of New England storms, including tropical cyclones and hurricanes, were created from the regional- to synoptic-scale historical data. For tropical cyclone candidates, characteristics were analyzed to ensure that a storm was indeed tropical (Mock, 2008). Records clearly exhibiting cold frontal passages, lack of an inner warm-core system, and falling V-shaped bar graphs were classified as extratropical, but all pre-1871 records were noted if they had winds gusting to gale or hurricane force during hurricane season. Data for each storm were also examined through descriptions of storm surge and damage to assess storm intensity consistent with the Saffir-Simpson scale.

\subsection{Reconstructed temperature variations in the NE US for the last 3000 years}

Both broad, Northern Hemisphere and highly localized variability in NE US paleoclimate has been examined in detail in previous publications. Here, we instead try to characterize the late Holocene climate in the NE US as a whole and focus on the similarities and differences that appear across multiple paleotemperature records from 3000 years ago to present (Fig. 5).

In the context of the full Holocene, NE US climate changes over the past 3 millennia are comparatively subtle (Shuman and Marsicek, 2016). A long-term cooling trend is evident, however, in most of the data, including the SST (Keigwin et al., 2003; Sachs, 2007) and pollen-based (Viau et al., 2006; Williams et al., 2011) temperature reconstructions (Fig. 5a, b, f, h). Although these data may be biased towards growing season climate, mean annual temperature reconstructions from the pollen data also show a slight cooling trend (Fig. 5f). Based on the average mean temperature of the warmest month (MTWA), peak summer warming occurs between 2500 and 3000 years ago, with generally declining temperatures thereafter until the most recent 2 centuries. Mean annual temperature anomalies (Viau et al., 2006) are also generally high prior to $2500 \mathrm{cal} \mathrm{yr} \mathrm{BP}$ and then show a subtle long-term decline (Fig. $5 \mathrm{f}$ ). The pollen-based temperature reconstruction from Trouet et al. (2013) shows cooling during most of the past millennium (Fig. $5 \mathrm{~g}$ ). Transient climate simulations from Liu et al. (2009) span the full late Holocene and show a slight decline in summer temperatures over the past 3000 years (Fig. $5 \mathrm{j}$ ), but non-simulated fall temperatures (not shown) show a much stronger longterm cooling, especially in September. Although they only span a bit more than the past millennium, the broad-scale tree-ring and multi-proxy reconstructions (Esper et al., 2012; Mann et al., 2009; Ljungqvist, 2010) and the Community Earth System Model-Last Millennium Ensemble (CESMLME) simulations (Otto-Bliesner et al., 2015) also all show a cooling trend (Fig. 5c, d, e, i). 


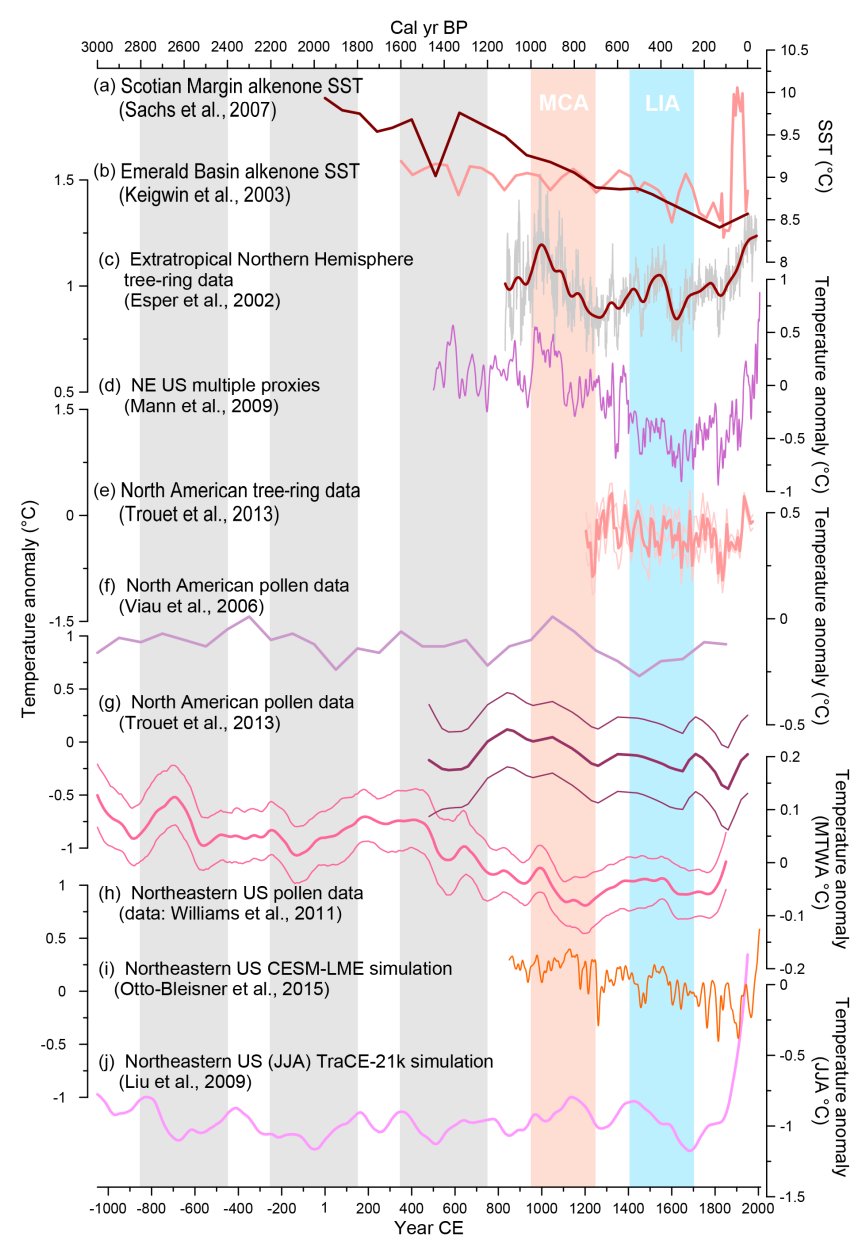

Figure 5. Temperature reconstructions for the last 3000 years for the NE US and adjacent regions, sourced from diverse paleoclimatic proxies and archives. (a) Sea surface temperature (SST) reconstructions based on $\mathrm{U}^{\mathrm{K}} 37$ in marine sediments (Sachs, 2007); (b) SST based on alkenone unsaturation in marine sediments (Keigwin et al., 2003); (c) tree-ring widths from the Northern Hemisphere extratropics (Esper et al., 2002); (d) northeastern US grid cells areally averaged (from 37.5 to $47.5^{\circ} \mathrm{N}$ latitude and 67.5 to $77.5^{\circ} \mathrm{W}$ longitude) from multiple proxies (Mann et al., 2009); (e) tree-ring widths from temperate North America (Trouet et al., 2013); (f) North American pollen data (Viau et al., 2006); (g) North American pollen data (Trouet et al., 2013); (h) northeastern pollen data (Williams et al., 2011); (i) NE US (39 to $46^{\circ} \mathrm{N}$ latitude and 67.5 to $97.5^{\circ} \mathrm{W}$ longitude) temperature simulation from the Community Earth System Model-Last Millennium Ensemble (Otto-Bliesner et al., 2015); (j) NE US temperature simulation from the Community Climate System Model version 3 SynTrace experiment (TraCE-21k; Liu et al., 2009). Vertical gray bands are only provided as a visual aid to identify the timing of features in the records. Pink and blue vertical bars mark the MCA and LIA intervals.

Differences in the pollen-based temperature reconstructions reflect a variety of differences in both data and methods. Viau et al. (2006), for example, used 752 pollen records and 4590 modern calibration samples, whereas Williams et al. (2011) used 863 pollen records that had updated age models based on linear interpolation between age controls (2004) and 4833 modern calibration samples (Whitmore et al., 2005). Both studies used slightly different versions of the modern analogue technique, which numerically compares the differences in the fossil pollen composition of each sediment sample with the composition of each modern sample from a calibration dataset. The environmental characteristics of the most similar modern samples are then averaged and assigned to the target fossil sample (Williams and Shuman, 2008). Data from Trouet et al. (2013) are from a broader source area. Differences in analysis methods and techniques, however, are likely less important than the differences in the underlying datasets, the age controls, and the smoothing methods. For the NE US, the Williams et al. (2011) reconstruction matches the domain most closely and is thus the most relevant (Fig. 5h).

The broad decline in temperatures during the past 3 millennia in the NE US is consistent with the continuation of neoglacial cooling since the early Holocene (Gajewski, 1987), attributed primarily to decreasing summer insolation. The bias towards summer season temperatures in most paleoclimate archives is well known. Tree rings (maximum latewood density), isotopic analyses from speleothems, and lake sediments, for example, all largely reflect summer processes (Hu et al., 2001). However, regional cooling is also evidenced by changes in forest composition, including increases in boreal forest components, such as spruce (Picea) and fir (Abies) (Davis, 1980; Jackson, 1989; Shuman et al., 2004; Oswald et al., 2007), and the pollen-based mean annual temperature reconstruction from Williams et al. (2011) reflects this (Fig. 5h).

Centennial-scale temperature variations are evident in many of the records, but only a few time periods show coherent changes across multiple data sources (which may partly reflect real spatial variability in climate). For example, a marked increase in temperature is evident at the onset of the MCA about 1000 years ago, particularly in the treering, multi-proxy, and pollen-based reconstructions (Fig. 5c, $\mathrm{d}, \mathrm{f}$, and $\mathrm{h}$ ). Hemispheric temperatures during the MCA were slightly lower than modern temperatures (Ahmed et al., 2013), and this appears true in the Mann et al. (2009) record, and in some of the pollen-based reconstructions (Fig. $5 \mathrm{c}-\mathrm{d}$, $\mathrm{h}-\mathrm{i}$ ), but these do not account for increasing human impacts on vegetation in recent centuries. Warming at the onset of the MCA generally gives way to continued cooling, and relatively low temperatures are recorded in all the proxies during the LIA. However, the broader-scale reconstructions (Fig. 5d, $\mathrm{e}, \mathrm{g})$ show their lowest temperatures at around $1800 \mathrm{CE}$. The two reconstructions specific to the NE US - the Williams et al. (2011) pollen-based temperature reconstruction and the Mann et al. (2009) multi-proxy reconstruction - and the Esper et al. (2002) tree-ring record show their lowest temperatures around $1600 \mathrm{CE}$. A general cooling during the LIA is consistent across all the reconstructions and simulations, 

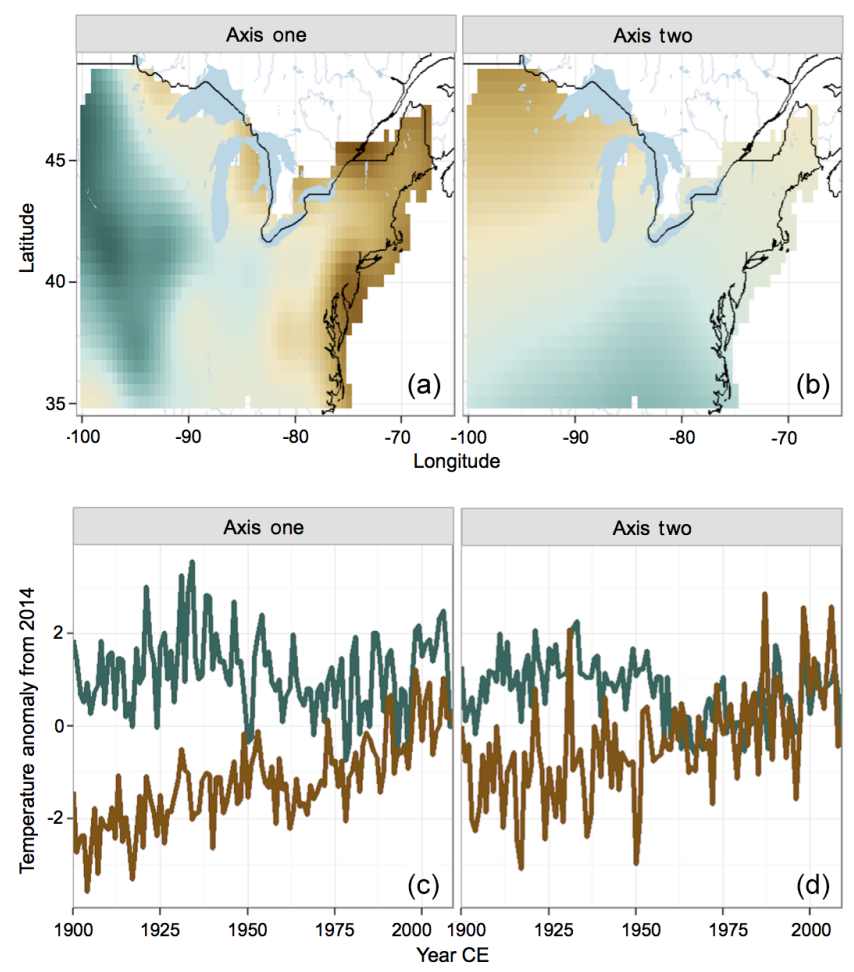

Figure 6. Broad-scale spatiotemporal patterns in the historical mean annual temperature anomalies from 1895-2010 from an empirical orthogonal function (EOF) analysis of data from the Global Historical Climatological Network for the NE US. (a) First EOF (16\% of the variance) showing a strong west-east (longitudinal) gradient in temperature changes during the last century, with the west (northwest especially) showing an early- to mid-century maximum and high variability (green line in panel c) and the Atlantic margin showing strong warming throughout the century (brown line in panel c). (b) Second EOF (accounting for $8 \%$ of the variance) indicating warming in the northwest but with higher variability (brown line in panel d) than along the Atlantic seaboard (brown line in panel c).

with the exception of the Viau et al. (2006) pollen-based reconstruction (Fig. 5f).

Recent warming is evident in most of the temperature reconstructions and also in the climate simulations, generally beginning 1 to 2 centuries ago and increasing steadily towards present. Historical temperature data become abundant at this time and offer more detailed insight into spatial patterns within the NE US (Fig. 6). Consistent with the National Climate Assessments from the Midwest and Northeast (Kunkel et al., 2013), EOF analysis of the historic weather station data from the GHCN indicates a general warming trend in both the eastern and western parts of the NE; there is a strong west-to-east gradient, however, over the past century (Fig. 6a, b). The EOFs account for 16 and $8 \%$ of the variance explained, respectively (the next are 5,4 , and $3 \%$, respectively). Large land-cover changes during the past century that have affected the hydrologic cycle and thus temperature patterns may partly account for the low variance explained (Portmann et al., 2009). The west (northwest especially) showed an early- to mid-century maximum in temperatures and high variability (green line in Fig. 6c), while the Atlantic margin experienced strong warming throughout the century (Fig. 6c, brown line). The second EOF (Fig. 6b, d) shows a northwest to northeast temperature gradient, which is largely inverse to the first EOF (Fig. 6a, c). In the secondary EOF pattern, higher variability is evident in the warming trend of annual temperatures from the northwest (Fig. 6d, brown line) than the same pattern along the Atlantic seaboard (Fig. 6c, brown line). Likewise, the early- to mid-century warm period (Fig. 6c, d, green lines) is less variable along the Atlantic seaboard (Fig. 6d) and smaller in magnitude than the same pattern in the northwest (Fig. 6c). Western and eastern NE US pollen-based temperature reconstructions show little difference, however (not shown), and the lack of other regional paleotemperature data limit finer spatial analyses within the domain prior to the historical era.

Given the limited regional NE US paleotemperature data, especially given that the Williams et al. (2011) pollen data have not been adjusted for recent human impacts, it is impossible to accurately compare modern- and late-Holocene temperature changes in this region. The recent reversal of the long-term cooling trend is clear in the broad-scale records, however. More detailed analyses of pollen and tree-ring data, along with continuing development of new regional paleotemperature reconstructions, are needed to better contextualize current warming and to examine the spatial expression of regional climate variations during the MCA and LIA. The relationship between seasonal variations and long-term trends also remains unclear but may be revealed with further analyses. Additional studies may also help determine synchrony and asynchrony of temperatures between the NE US and other regions.

\subsection{Reconstructed hydroclimate variations in the NE US for the last 3000 years}

Paleohydrological records are more abundant than paleotemperature records in the NE US (Fig. 7), but as with the temperature records, more data are available near the coast than inland. Tree rings (Fig. 7a), varve thicknesses (Fig. 7b), lake levels (Fig. $7 \mathrm{~g}$ ), and simulations (Fig. $7 \mathrm{~h}$ ) can provide information about trends, but the bog (Fig. 7c), SVR (Fig. 7e), and IRM data (Fig. 7f) are more suited to capturing discrete events. Together, the tree-ring PDSI (especially from the coastal areas), varve, and lake level records indicate a long-term increase in effective moisture throughout the past 3000 years, with more evidence accumulating towards present (Fig. 7a, b, g). The bog records, which are divided into western (from Michigan and Indiana) and eastern sites (from Maine), do not appear to show a substantial increase or decrease in the number of events over time. 
Cal yr BP
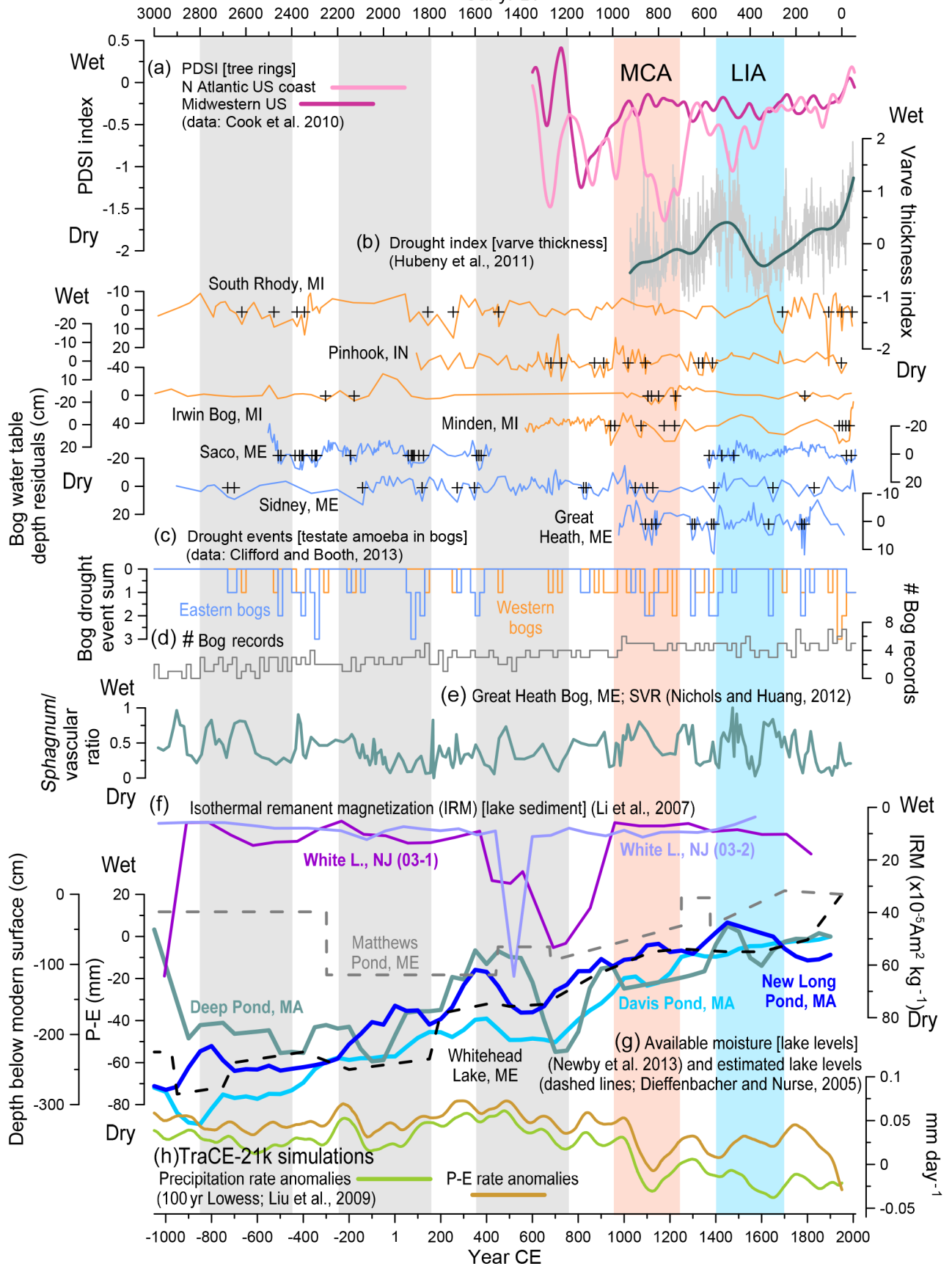

Figure 7. Hydroclimatic reconstructions for the last 3000 years for the NE US and adjacent regions, sourced from diverse paleoclimatic proxies and archives. (a) Tree-ring-based reconstructions of PDSI (Cook et al., 2010); (b) composite index of two varve thickness records from Green Lake, New York, and the Pettaquamscutt River Estuary, Rhode Island (Hubeny et al., 2011); (c) drought events (marked with “+”) and event summary based on water table reconstructions from testate amoeba in western kettle-hole peatlands (Pinhook and South Rhody), western bogs (Irwin Smith and Minden), and eastern bogs (Sidney, Saco, and Great Heath; Booth and Jackson, 2003; Booth et al., 2006, 2012; Clifford and Booth, 2013); (d) bog record counts; (e) ratio of Sphagnum to vascular plants from the Great Heath Bog, Maine (Nichols and Huang, 2012); (f) drought indicator based on isothermal remanent magnetization at White Lake, New Jersey (Li et al., 2007); (g) lake level reconstructions from Deep, Davis, and New Long ponds in Massachusetts (Marsicek et al., 2013; Newby et al., 2014) and lake level change estimates from Mathews Pond and Whitehead Lake, Maine (Dieffenbacher-Krall and Nurse, 2005); and (h) precipitation and $P-E$ rate anomalies from the TraCE-21k simulations (Liu et al., 2009). Vertical gray bands are only provided as a visual aid to identify the timing of features in the records. Pink and blue vertical bars mark the well-known MCA and LIA intervals. 


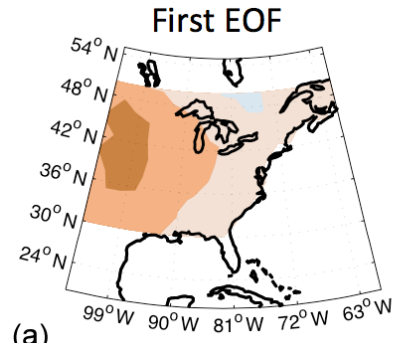

(a)

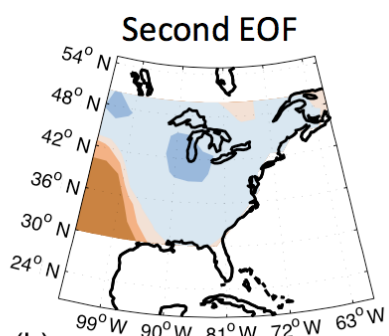

(b)

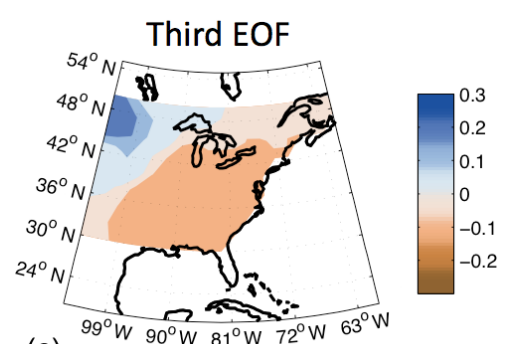

(c)

Figure 8. NADA spatial structure and signals. First three EOFs for the 2.5 NADA. Calculated for 1700-2005. Variance explained: 13, 9 , and $8 \%$. Colors indicate areas with opposite loading patterns for relatively wet versus dry conditions.

Centennial-scale variability is superimposed on the records showing a long-term trend, suggesting that large droughts and pluvials (anomalously wet periods) were not uncommon in the past 3000 years. The earliest period of drought that appears in multiple records occurs in the eastern bog sites (Fig. 7c, blue) around $400 \mathrm{BCE}$ and $100 \mathrm{CE}$. The SVR and lake levels also indicate relatively dry conditions compared to the past millennium.

The lake level, IRM, and tree-ring data (Fig. 7a, f, g) together suggest that marked shifts in hydroclimate also occurred between 300 and $800 \mathrm{CE}$, or between 1650 and 1150 years ago. The lake level and IRM data both indicate a long period of drought from about 550 to 750 CE (1400$1200 \mathrm{cal} \mathrm{yr} \mathrm{BP}$ ). Sluice Pond in northeastern Massachusetts (Hubeny et al., 2015) and Piermont Marsh in the Hudson Valley, though not included in this synthesis, also indicate drought during this interval (Pederson et al., 2005). The PDSI reconstruction from tree rings (Fig. 7a) shows high variability from 400 to $600 \mathrm{CE}$ as well.

Many of the NE US hydroclimate records indicate dry conditions during the MCA. Around 1100 CE the Atlantic PDSI reconstruction shows a large departure indicating prolonged, widespread drought (Fig. 7a), and the varve thickness index (Fig. 7b) also shows very dry conditions. Both the western and eastern bog sites show frequent drought during the MCA as well (Fig. 7c). Drought is not evident in the lake level reconstructions during the MCA, however (Fig. $7 \mathrm{~g}$ ), whereas reduced precipitation is evident in the TraCE- $21 \mathrm{k}$ simulations, both in the precipitation rate anomalies and in the $P-E$ rate anomalies (Fig. 7h).

The transition from the MCA to the LIA at about $1400 \mathrm{CE}$ brings an increase in moisture or a decrease in drought events in most records, including tree rings (Fig. 7a), varve thicknesses (Fig. 7b), the bog records (Fig. 7c), the SVR record (Fig. 7e), and the lake levels (Fig. 7g). Progressively wetter conditions follow in the PDSI and varve records, which both have annual resolution and are strongly correlated with instrumental records (Fig. 7a, b).

Considering the NE US moisture records (Fig. 7) in the context of the temperature records (Fig. 5) highlights some relationships in the timing of climate changes and hints at

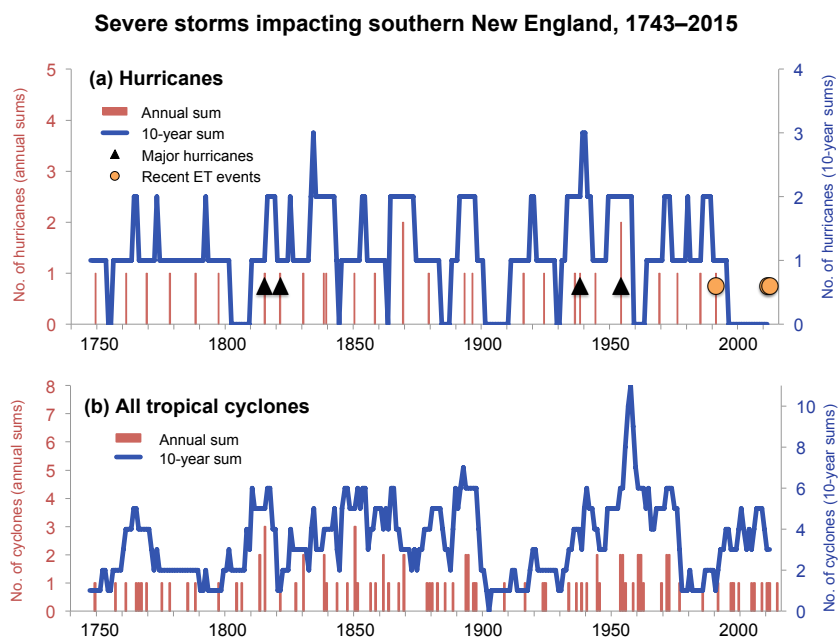

Figure 9. Annual number and decadal sums for (a) reconstructed hurricanes and (b) tropical cyclones and hurricanes in southern New England from 1743 to 2015 CE. Major hurricanes (i.e., SaffirSimpson Category 3, 4, or 5) are shown as triangles. Selected recent extratropical storms (the Perfect Storm of 1991, the Halloween Nor'easter of 2011, and post-Hurricane Sandy in 2012) are shown as circles. Methodology for the storm reconstructions follow those outlined in Mock (2008).

synoptic climate controls. Cold intervals recorded in the SST (Fig. 5a, b) and two of the pollen datasets (Fig. 5g, h) around $500 \mathrm{CE}$, for example, coincide with drought events in the IRM and some of the lake level data (Fig. 7f, g). The timing is not consistently synchronous in these records, but this period is characterized in general by relatively large shifts in both temperature and moisture. Such oscillations alone may help explain a sharp rise in chestnut and hemlock in the Northeast coupled with a large increase in charcoal influx in some areas around the same time (Foster et al., 2002; Parshall et al., 2003). Similarly large climate shifts are observed in both the temperature and hydroclimate records during the MCA, particularly around $1000 \mathrm{CE}$, and throughout the LIA. Given the limitations and diversity of the current paleoclimate dataset for the NE US, further exploration of potential synoptic cli- 
mate influences on these events is beyond the scope of the current study.

In the most recent century, an acceleration of the gradual wetting trend is observed in PDSI records, the varve index, and the lake level reconstruction from Whitehead Lake. The SVR and western bog records, in contrast, show increasing drought events during recent centuries. Given the complexities of droughts, which have unique spatial signatures, severities, durations, and other characteristics, it is not surprising that different recorders of drought may show diverging patterns. In addition to the physical differences that may register in different proxies, many bogs (Great Heath in particular) have experienced increasing human influences in recent centuries that may have disturbed water levels. Uncertainties therefore also increase in the recent past in these records. Another factor that may contribute to differences in results more generally are seasonality differences. With the exception of the lake level records, the hydroclimate data (like the temperature proxies) may overrepresent growing season relative to annual changes.

Some insight can be gained into the spatial differences in drought by comparing PDSI reconstructions from different subregions, as apparent in the unique trends from the Midwestern and North Atlantic coastal sites (Fig. 7a). The MCA and LIA dry intervals apparent in the easternmost sites, for example, do not appear in the Midwestern sites. Spatial structure in NE US drought can also be observed through EOF analysis of the NADA data (Fig. 8). From 1700 to 2005 CE, there are three primary patterns, although none of these explain substantial variance. The strongest pattern $(13 \%$ of the variance explained) shows drought centered in the Midwest similar to the historical drought of 1931-1940 (the "Dust Bowl"). The second EOF ( $9 \%$ of the variance) has a pattern similar to the southwest drought of 1950-1957. A third EOF (explaining $8 \%$ of the variance) reflects widespread drought in the southeast similar to the 1889-1896 event (Herweijer et al., 2005) and also to the 1960s drought. The low variance explained by any one particular EOF means that drought patterns have been heterogeneous in the recent past. The pattern reflected in the third EOF, however, reinforces the notion that widespread drought in the east is not uncommon.

Short-lived disturbances, such as storms, can have dramatic impacts on ecosystems in the NE US (Besonen et al., 2008; Donnelly et al., 2001) but are considered less often in paleoclimate studies because they are very difficult to reconstruct. Erosion patterns inferred from particle size variations in six northern New England lakes suggest an increase in extreme precipitation events during recent millennia, for example in Parris et al. (2010), but Noren et al. (2002) tell a slightly different story with the same approach for New Hampshire. A synthesis of all New England storms of at least tropical storm impact shows no long-term trend in either hurricanes or all tropical cyclones (Fig. 9). Storm activity was high in the 1950s, however, and low in the early 20 th century and mid-to-late 18 th century. The storminess during the 1950s may be part of a broader pattern of Atlantic hurricane activity related to the Atlantic Multidecadal Oscillation (e.g., Goldenberg et al., 2001). About 0-2 have hurricanes occurred per year since 1743, and major hurricanes (Category 3, 4, or 5 on the Saffir-Simpson scale) are very rare. Relative stability in hurricane occurrence during the past 260 years highlights the importance of unique daily synoptic patterns conducive for tracking storms towards New England and suggests that forcings like solar activity and greenhouse gases have had limited effect on overall numbers in New England. Storm activity does not appear anomalous during the end of the LIA. Some past storms with hurricaneforce winds are likely similar to those in recent memory, such as post-Hurricane Sandy in 2012, the Perfect Storm in 1991, and the Halloween Nor'easter of 2011.

\section{Conclusions}

With the exception of fossil pollen records, there are a limited number of northeastern US (NE US) paleoclimate archives that can provide constraints on its temperature and hydroclimate history. The regional paleoclimate data that do exist suggest that the current warming and wetting trend reflects a reversal of millennial-scale cooling and wetting trends prior to the 1800 s, although seasonal differences in proxy sensitivities complicate interpretation. Nonetheless, pollen data, coastal SST marine records, and broader-scale multi-proxy networks suggest regional preindustrial cooling over the late Holocene. Evidence for a trend towards wetter conditions in the past 3000 years is strong in the lake level data and for the past millennium in additional hydroclimate data.

Hydroclimate reconstructions from testate amoeba in bogs are a particularly promising resource for paleoclimate studies because their spatiotemporal domain overlaps many other proxies (Fig. 3), and they show strong correlations with local PDSI data (Booth, 2010). These data can therefore provide an independent source of convergent evidence for local droughts and other changes. However, understanding regional changes with testate amoeba records is difficult because they do not reliably record low-frequency trends. Further analyses of drought frequencies or of other drought characteristics may make WTD reconstructions more comparable to other hydroclimatic proxies and more useful in modeling contexts.

Taken together, currently available paleoevidence suggests that the NE US climate became generally cooler and wetter during the late Holocene. The MCA was also substantially warmer and drier than the LIA along the Atlantic coast. Prior to the MCA, the NE US climate remained generally drier than present with highly uncertain but likely relatively warm temperature conditions. Multiple types of paleodata from sediments and trees suggest that major droughts in the late Holocene were not uncommon in the NE US. Two particularly dry periods occurred around $700 \mathrm{CE}$ and again 
around $1100 \mathrm{CE}$ during the MCA. No trend is evident in storm frequency in New England, but increasing rates of change in both growing season temperature and moisture will likely have significant impacts on vegetation and disturbance regimes. New calibrated paleoclimate records will help constrain spatiotemporal variations in temperature and precipitation in the NE.

Data availability. Datasets used in this paper that were previously published are available from sources identified in the text. Data included that were not previously available from public archives can be obtained from the Long Term Ecological Research Network data portal: https://doi.org/10.6073/pasta/6ced33c5e07f9fa7f1 lefb259001bacb.

Author contributions. JRM, BS, SG, CN, and NP designed the study, RB, EC, ADK, CM, CU, JN, NP, BS, and ZY provided data, JRM, SG, CN, and PJB analyzed the data, JRM, NP, and SG wrote the initial draft, and all authors contributed to writing and editing.

Acknowledgements. We thank Matthew Montanaro for assistance with data analysis. This work was supported by NSF grant EF-1065732 to Stephen T. Jackson, John W. Williams, and Jennifer R. Marlon and by NSF grant EF-1241870 to Jennifer R. Marlon, Neil Pederson, Robert Booth, Stephen T. Jackson, Jennifer R. Marlon, David J. P. Moore, and John W. Williams. Neil Pederson was supported by NSF grant AGS-1304262. Jennifer R. Marlon was supported by NSF grant BCS-1437074.

Edited by: Zhengtang Guo

Reviewed by: two anonymous referees

\section{References}

Ahmed, M., Anchukaitis, K. J., Asrat, A., Borgaonkar, H. P., Braida, M., Buckley, B. M., Büntgen, U., Chase, B. M., Christie, D. A., and Cook, E. R.: Continental-Scale Temperature Variability During the Past Two Millennia, Nat. Geosci., 6, 339-346, 2013.

Almendinger, J.: A groundwater model to explain past lake levels at barkers Prairie, Minnesota, USA, Holocene, 3, 105-115, 1993.

Almquist, H., Dieffenbacher-Krall, A. C., Flanagan-Brown, R., and Sanger, D.: The Holocene record of lake levels of Mansell Pond, central Maine, USA, Holocene, 11, 189-201, 2001.

Anderson, B., Hayhoe, K., and Liang, X.-Z.: Anthropogenicinduced changes in twenty-first century summertime hydroclimatology of the Northeastern US, Climatic Change, 99, 403423, 2010.

Austin, J. A. and Colman, S. M.: Lake Superior summer water temperatures are increasing more rapidly than regional air temperatures: A positive ice-albedo feedback, Geophys. Res. Lett., 34, L06604, https://doi.org/10.1029/2006GL029021, 2007.

Balco, G., Belknap, D., and Kelley, J.: Paleoclimatic Implications of Holocene Lake-Level Fluctuations, Owasco Lake, New York, A Comment, Geology, 25, 383-384, 1997.
Balco, G., Belknap, D. F., and Kelley, J. T.: Glacioisostasy and lakelevel change at Moosehead Lake, Maine, Quaternary Res., 49, 157-170, 1998.

Bartlein, P. and Webb, T. I.: Mean July temperature at $6000 \mathrm{yr}$ B.P. in eastern North America: regression equations for estimates from fossil-pollen data, Syllogeus, 55, 301-342, 1985.

Bartlein, P., Harrison, S., Brewer, S., Connor, S., Davis, B., Gajewski, K., Guiot, J., Harrison-Prentice, T., Henderson, A., Peyron, O., Prentice, C., Scholze, M., Seppä, H., Shuman, B., Sugita, S., Thompson, R., Viau, A., Williams, J., and Wu, H.: Pollen-based continental climate reconstructions at 6 and $21 \mathrm{ka}$ : a global synthesis, Clim. Dynam., 37, 775-802, 2011.

Battarbee, R., Anderson, N., Bennion, H., and Simpson, G.: Combining limnological and palaeolimnological data to disentangle the effects of nutrient pollution and climate change on lake ecosystems: problems and potential, Freshwater Biol., 57, 20912106, 2012.

Besonen, M. R., Bradley, R. S., Mudelsee, M., Abbott, M. B., and Francus, P.: A 1,000-year, annually-resolved record of hurricane activity from Boston, Massachusetts, Geophys. Res. Lett., 35, L14705, https://doi.org/10.1029/2008GL033950, 2008.

Bhuta, A. A., Kennedy, L. M., and Pederson, N.: Climate-radial growth relationships of northern latitudinal range margin longleaf pine (Pinus palustris P. Mill.) in the Atlantic coastal plain of southeastern Virginia, Tree-Ring Res., 65, 105-115, 2009.

Birks, H. H.: Plant macrofossils, in: Tracking environmental change using lake sediments, Springer, 49-74, 2002.

Birks, H. H. and Birks, H.: Future uses of pollen analysis must include plant macrofossils, J. Biogeogr., 27, 31-35, 2000.

Bishop, D. A. and Pederson, N.: Regional Variation of Transient Precipitation and Rainless-day Frequency Across a Subcontinental Hydroclimate Gradient, Journal of Extreme Events, 2, 1550007, https://doi.org/10.1142/S2345737615500074, 2015.

Black, B. A., Griffin, D., van der Sleen, P., Wanamaker, A. D., Speer, J. H., Frank, D. C., Stahle, D. W., Pederson, N., Copenheaver, C. A., Trouet, V., and Griffin, S.: The value of crossdating to retain high-frequency variability, climate signals, and extreme events in environmental proxies, Glob. Change Biol., 22, 2582 2595, 2016.

Blois, J., Williams, J., Grimm, E., Jackson, S., and Graham, R.: A methodological framework for improved paleovegetation mapping from late-Quaternary pollen records, Quaternary Sci. Rev., 30, 1926-1939, 2011.

Boeff, K. A., Strock, K. E., and Saros, J. E.: Evaluating planktonic diatom response to climate change across three lakes with differing morphometry, J. Paleolimnol., 56, 33-47, 2016.

Bond, G., Kromer, B., Beer, J., Muscheler, R., Evans, M., Showers, W., Hoffmann, S., Lotti-Bond, R., Hajdas, I., and Bonani, G.: Persistent solar influence on north Atlantic climate during the Holocene, Science, 294, p. 2130, 2001.

Booth, R., Lamentowicz, M., and Charman, D.: Preparation and analysis of testate amoebae in peatland paleoenvironmental studies, Mires and Peat, 7, 1-7, 2010.

Booth, R. K.: Testate amoebae as proxies for mean annual water table depth in Sphagnum dominated peatlands of North America, J. Quaternary Sci., 23, 43-57, 2008.

Booth, R. K.: Testing the climate sensitivity of peat-based paleoclimate reconstructions in mid-continental North America, Quaternary Sci. Rev., 29, 720-731, 2010. 
Booth, R. K. and Jackson, S. T.: A high-resolution record of lateHolocene moisture variability from a Michigan raised bog, USA, Holocene, 13, 863-876, 2003.

Booth, R. K., Jackson, S. T., and Thompson, T. A.: Paleoecology of a northern Michigan lake and the relationship among climate, vegetation, and Great Lakes water levels, Quaternary Res., 57, 120-130, 2002.

Booth, R. K., Notaro, M., Jackson, S. T., and Kutzbach, J. E.: Widespread drought episodes in the western Great Lakes region during the past 2000 years: geographic extent and potential mechanisms, Earth Planet. Sc. Lett., 242, 415-427, 2006.

Booth, R. K., Jackson, S. T., Sousa, V. A., Sullivan, M. E., Minckley, T. A., and Clifford, M. J.: Multi-decadal drought and amplified moisture variability drove rapid forest community change in a humid region, Ecology, 93, 219-226, 2012.

Bradbury, J.: Charcoal deposition and redeposition in Elk Lake, Minnesota, Holocene, 6, 349-344, 1996.

Brassell, S., Eglinton, G., Marlowe, I., Pflaumann, U., and Sarnthein, M.: Molecular stratigraphy: a new tool for climatic assessment, Nature, 320, 129-133, 1986.

Castañeda, I. S., Werne, J. P., Johnson, T. C., and Powers, L. A.: Organic geochemical records from Lake Malawi (East Africa) of the last 700 years, part II: Biomarker evidence for recent changes in primary productivity, Palaeogeogr. Palaeocl., 303, 140-154, 2011.

Charman, D. J. and Blundell, A.: A new European testate amoebae transfer function for palaeohydrological reconstruction on ombrotrophic peatlands, J. Quaternary Sci., 22, 209-221, 2007.

Charman, D. J., Brown, A. D., Hendon, D., and Karofeld, E.: Testing the relationship between Holocene peatland palaeoclimate reconstructions and instrumental data at two European sites, Quaternary Sci. Rev., 23, 137-143, 2004.

Charman, D. J., Blundell, A., Chiverrell, R. C., Hendon, D., and Langdon, P. G.: Compilation of non-annually resolved Holocene proxy climate records: stacked Holocene peatland palaeo-water table reconstructions from northern Britain, Quaternary Sci. Rev., 25, 336-350, 2006.

Charman, D. J., Barber, K. E., Blaauw, M., Langdon, P. G., Mauquoy, D., Daley, T. J., Hughes, P. D., and Karofeld, E.: Climate drivers for peatland palaeoclimate records, Quaternary Sci. Rev., 28, 1811-1819, 2009.

Clifford, M. J. and Booth, R. K.: Increased probability of fire during late Holocene droughts in northern New England, Climatic Change, 119, 693-704, 2013.

Clifford, M. J. and Booth, R. K.: Late-Holocene drought and fire drove a widespread change in forest community composition in eastern North America, Holocene, 25, 1102-1110, 2015.

Conkey, L. E.: Eastern US Tree-ring Widths and Densities as Indicators of Past Climate, PhD thesis, 1982.

Conkey, L. E.: Red spruce tree-ring widths and densities in eastern North America as indicators of past climate, Quaternary Res., 26, 232-243, 1986.

Cook, E. and Krusic, P.: North American summer PDSI reconstructions, IGBP PAGES/World Data Center for Paleoclimatology Data Contribution Series, 45, 2004.

Cook, E. and Krusic, P.: North American summer PDSI reconstructions, version 2a, IGBP PAGES/World Data Center for Paleoclimatology Data Contribution Series, 46, 2008, 2008.
Cook, E. R.: Tree rings as indicators of climatic change and the potential response of forests to the greenhouse effect, Global climate change and life on earth. London, Routledge: Chapman \& Hall, 56-64, 1991.

Cook, E. R. and Kairiukstis, L. A.: Methods of dendrochronology: applications in the environmental sciences, Springer Science and Business Media, 1990.

Cook, E. R. and Pederson, N.: Uncertainty, emergence, and statistics in dendrochronology, Springer, 77-112, 2011.

Cook, E. R. and Peters, K.: Calculating unbiased tree-ring indices for the study of climatic and environmental change, Holocene, 7 , 361-370, 1997.

Cook, E. R., Woodhouse, C. A., Eakin, C. M., Meko, D. M., and Stahle, D.: Long-term aridity changes in the western United States, Science, 306, 1015-1018, 2004.

Cook, E. R., Anchukaitis, K. J., Buckley, B. M., D’Arrigo, R. D., Jacoby, G. C., and Wright, W. E.: Asian monsoon failure and megadrought during the last millennium, Science, 328, 486-489, 2010.

Crucifix, M.: Traditional and novel approaches to palaeoclimate modelling, Quaternary Sci. Rev., 57, 1-16, 2012.

Davis, M.: Holocene Climate of New England, Quaternary Res., 14, 240-250, 1980.

Dieffenbacher-Krall, A. C. and Nurse, A. M.: Late-glacial and Holocene record of lake levels of Mathews Pond and Whitehead Lake, northern Maine, USA, J. Paleolimnol., 34, 283-309, 2005.

Digerfeldt, G.: Studies on past lake-level fluctuations, Handbook of Holocene palaeoecology and palaeohydrology, 127, p. 143, 1986.

Digerfeldt, G., Almendinger, J. E., and Björck, S.: Reconstruction of past lake levels and their relation to groundwater hydrology in the Parkers Prairie sandplain, west-central Minnesota, Palaeogeogr. Palaeocl., 94, 99-118, 1992.

Donnelly, J. P., Roll, S., Wengren, M., Butler, J., Lederer, R., and Webb, T.: Sedimentary evidence of intense hurricane strikes from New Jersey, Geology, 29, 615-618, 2001.

Donovan, J. J., Smith, A. J., Panek, V. A., Engstrom, D. R., and Ito, E.: Climate-driven hydrologic transients in lake sediment records: calibration of groundwater conditions using 20th century drought, Quaternary Sci. Rev., 21, 605-624, 2002.

Eglinton, G. and Hamilton, R. J.: Leaf epicuticular waxes, Science, 156, 1322-1335, 1967.

Eglinton, T. I. and Eglinton, G.: Molecular proxies for paleoclimatology, Earth Planet. Sc. Lett., 275, 1-16, 2008.

Esper, J., Cook, E. R., and Schweingruber, F.: Low-Frequency Signals in Long Tree-Ring Chronologies for Reconstructing Past Temperature Variability, Science, 295, 2250-2253, 2002.

Esper, J., Frank, D. C., Timonen, M., Zorita, E., Wilson, R. J., Luterbacher, J., Holzkämper, S., Fischer, N., Wagner, S., Nievergelt, D., and Verstege, A.: Orbital forcing of tree-ring data, Nature Climate Change, 2, 862-866, 2012.

Evans, M. N., Tolwinski-Ward, S. E., Thompson, D. M., and Anchukaitis, K. J.: Applications of proxy system modeling in high resolution paleoclimatology, Quaternary Sci. Rev., 76, 16-28, 2013.

Foster, D. R., Clayden, S., Orwig, D. A., Hall, B., and Barry, S.: Oak, chestnut and fire: climatic and cultural controls of longterm forest dynamics in New England, USA, J. Biogeogr., 29, 1359-1379, 2002. 
Freeman-Lynde, R., Hutchinson, D., Folger, D., Wiley, B., and Hewett, M.: The origin and distribution of subbottom sediments in southern Lake Champlain, Quaternary Res., 14, 224-239, 1980.

Fritts, H. C.: Tree rings and climate, Academic Press, London, 1976.

Fritz, S.: Paleolimnological records of climatic change in North America, Limnol. Oceanogr., 41, 882-889, 1996.

Fritz, S. C., Ito, E., Yu, Z., Laird, K. R., and Engstrom, D. R.: Hydrologic variation in the northern Great Plains during the last two millennia, Quaternary Res., 53, 175-184, 2000.

Fuller, J. L., Foster, D. R., McLachlan, J. S., and Drake, N.: Impact of human activity on regional forest composition and dynamics in central New England, Ecosystems, 1, 76-95, 1998.

Fye, F. K., Stahle, D. W., and Cook, E. R.: Paleoclimatic analogs to twentieth-century moisture regimes across the United States, B. Am. Meteorol. Soc., 84, 901-909, 2003.

Gajewski, K.: Climatic impacts on the vegetation of eastern North America during the past 2000 years, Vegetatio, 68, 179-190, 1987.

Gajewski, K.: Late Holocene climate changes in eastern North America estimated from pollen data, Quaternary Res., 29, 255262, 1988.

Garreta, V., Miller, P. A., Guiot, J., Hély, C., Brewer, S., Sykes, M. T., and Litt, T.: A method for climate and vegetation reconstruction through the inversion of a dynamic vegetation model, Clim. Dynam., 35, 371-389, 2010.

Geiss, C. E., Umbanhowar, C. E., Camill, P., and Banerjee, S. K.: Sediment magnetic properties reveal Holocene climate change along the Minnesota prairie-forest ecotone, J. Paleolimnol., 30, 151-166, 2003.

George, S. S. and Nielsen, E.: Hydroclimatic change in southern Manitoba since AD 1409 inferred from tree rings, Quaternary Res., 58, 103-111, 2002.

Gignac, L. D.: Bryophytes as indicators of climate change, The Bryologist, 104, 410-420, 2001.

Goldenberg, S. B., Landsea, C. W., Mestas-Nuñez, A. M., and Gray, W. M.: The recent increase in Atlantic hurricane activity: Causes and implications, Science, 293, 474-479, 2001.

Goring, S., Williams, J., Blois, J., Jackson, S., Paciorek, C., Booth, R., Marlon, J., Blaauw, M., and Andres, C.: Deposition times in the northeastern United States during the Holocene: establishing valid priors for Bayesian age models, Quaternary Sci. Rev., 48, 54-60, 2012.

Hayhoe, K., Wake, C., Huntington, T., Luo, L., Schwartz, M., Sheffield, J., Wood, E., Anderson, B., Bradbury, J., DeGaetano, A., Troy, T., and Wolfe, D.: Past and future changes in climate and hydrological indicators in the US Northeast, Clim. Dynam., 28, 381-407, 2007.

Herbert, T.: Review of alkenone calibrations (culture, water column, and sediments), Geochem. Geophy. Geosy., 2, 1055, https://doi.org/10.1029/2000GC000055, 2001.

Herweijer, C., Seager, R., Cook, E. R., and Emile-Geay, J.: North American Droughts of the Last Millennium from a Gridded Network of Tree-Ring Data, J. Climate, 20, 1353-1376, 2005.

Hodgkins, G. A.: The importance of record length in estimating the magnitude of climatic changes: an example using 175 years of lake ice-out dates in New England, Climatic change, 119, 705718,2013
Hopton, H. M. and Pederson, N.: Climate sensitivity of Atlantic white cedar at its northern range limit, in: Atlantic White Cedar: Ecology, Restoration and Management: Proceedings of the Arlington Echo Symposium. Gen. Tech. Rep. SRS-91. USDA-Forest Service, Southern Research Station, Asheville, NC, Asheville, NC, USDA Forest Service Southern Research Station, 22-30, 2005.

Horton, R., Yohe, G., Easterling, W., Kates, R., Ruth, M., Sussman, E., Whelchel, A., Wolfe, D., and Lipschultz, F.: Climate Change Impacts in the United States: The Third National Climate Assessment, chap. 16, U.S. Global Change Research Program, 16$1-\mathrm{nn}, 2014$.

Hou, J., Huang, Y., Wang, Y., Shuman, B., Oswald, W., Faison, E., and Foster, D.: Postglacial climate reconstruction based on compound-specific $\mathrm{D} / \mathrm{H}$ ratios of fatty acids from Blood Pond, New England, Geochem. Geophy. Geosy., 7, Q03008, https://doi.org/10.1029/2005GC001076, 2006.

Hou, J., Huang, Y., Oswald, W., Foster, D., and Shuman, B.: Centennial-scale compound-specific hydrogen isotope record of Pleistocene-Holocene climate transition from southern New England, Geophys. Res. Lett., 34, L19706, https://doi.org/10.1029/2007GL030303, 2007.

Hu, F., Ito, E., Brown, T., Curry, B., and Engstrom, D.: Pronounced climatic variations in Alaska during the last two millennia, $\mathrm{P}$. Natl. Acad. Sci. USA, 98, 10552-10556, 2001.

Huang, Y., Shuman, B., Wang, Y., and Webb III, T.: Hydrogen isotope ratios of palmitic acid in lacustrine sediments record lateQuaternary climate variations, Geology, 30, 1103-1106, 2002.

Hubeny, J. B., King, J. W., and Reddin, M.: Northeast US precipitation variability and North American climate teleconnections interpreted from late Holocene varved sediments, P. Natl. Acad. Sci. USA, 108, 17895-17900, 2011.

Hubeny, J. B., McCarthy, F. M., Lewis, J., Drljepan, M., Morissette, C., King, J. W., Cantwell, M., Hudson, N. M., and Crispo, M. L.: The paleohydrology of Sluice Pond, NE Massachusetts, and its regional significance, J. Paleolimnol., 53, 271-287, 2015.

Hutchinson, D., Ferrebee, W., Knebel, H., Wold, R., and Isachsen, Y.: The sedimentary framework of the southern basin of Lake George, New York, Quaternary Res., 15, 44-61, 1981.

Jackson, S., Webb, R., Anderson, K., Overpeck, J., Webb, T. I., Williams, J., and Hansen, B.: Vegetation and environment in unglaciated eastern North America during the last glacial maximum, Quaternary Sci. Rev., 19, 489-508, 2000.

Jackson, S. T.: Postglacial vegetational changes along an elevational gradient in the Adirondack Mountains (New York): a study of plant macrofossils, University of the State of New York, State Education Department, New York State Museum, Biological Survey, 1989.

Juggins, S. and Birks, H. J. B.: Quantitative environmental reconstructions from biological data, in: Tracking environmental change using lake sediments, Springer, 431-494, 2012.

Karl, T. R.: Global climate change impacts in the United States, Cambridge University Press, 2009.

Karner, M. B., DeLong, E. F., and Karl, D. M.: Archaeal dominance in the mesopelagic zone of the Pacific Ocean, Nature, 409, 507510, 2001.

Keigwin, L. D., Sachs, J. P., and Rosenthal, Y.: A 1600-year history of the Labrador Current off Nova Scotia, Clim. Dynam., 21, 5362,2003 
Kunkel, K. E., Stevens, L. E., Stevens, S. E., Sun, L., Janssen, E., Wuebbles, D., Rennells, J., DeGaetano, A., and Dobson, J. G.: Regional Climate Trends and Scenarios for the U.S. National Climate Assessment: Part 1. Climate of the Northeast U.S., 2013.

Leng, M. J. and Marshall, J. D.: Palaeoclimate interpretation of stable isotope data from lake sediment archives, Quaternary Sci. Rev., 23, 811-831, 2004.

Li, Y.-X., Yu, Z. C., and Kodama, K. P.: Sensitive moisture response to Holocene millennial-scale climate variations in the Mid-Atlantic region, USA, Holocene, 1, 3-8, 2007.

Lindbladh, M., Jacobson, G. L., and Schauffler, M.: The postglacial history of three Picea species in New England, USA, Quaternary Res., 59, 61-69, 2003.

Liu, Z., Otto-Bliesner, B. L., He, F., Brady, E. C., Tomas, R., Clark, P. U., Carlson, A. E., Lynch-Stieglitz, J., Curry, W., Brook, E., Erickson, D., Jacob, R., Kutzbach, J., and Cheng, J.: Transient simulation of last deglaciation with a new mechanism for BollingAllerod warming, Science, 325, 310-314, 2009.

Ljungqvist, F.: A new reconstruction of temperature variability in the extra-tropical northern hemisphere during the last two millennia, Geogr. Ann. A, 92, 339-351, 2010.

Loader, C.: Locfit: Local regression, likelihood and density estimation, R package version, 1, 2007.

Mann, M., Zhang, Z., Rutherford, S., Bradley, R. S., Hughes, M. K., Shindell, D., Ammann, C., Faluvegi, G., and Ni, F.: Global signatures and dynamical origins of the Little Ice Age and Medieval Climate Anomaly, Science, 326, 1256-1260, 2009.

Marcott, S. A., Shakun, J. D., Clark, P. U., and Mix, A. C.: A reconstruction of regional and global temperature for the past 11,300 years, Science, 339, 1198-1201, 2013.

Marsicek, J. P., Shuman, B., Brewer, S., Foster, D. R., and Oswald, W. W.: Moisture and temperature changes associated with the mid-Holocene Tsuga decline in the northeastern United States, Quaternary Sci. Rev., 80, 129-142, 2013.

Mason, I., Guzkowska, M., Rapley, C., and Street-Perrott, F.: The response of lake levels and areas to climatic change, Climatic change, 27, 161-197, 1994.

Maxwell, R. S., Hessl, A. E., Cook, E. R., and Pederson, N.: A multispecies tree ring reconstruction of Potomac River streamflow (950-2001), Water Resour. Res., 47, W05512, https://doi.org/10.1029/2010WR010019, 2011.

McEwan, R., Dyer, J., and Pedersen, N.: Multiple interacting ecosystem drivers: toward an encompassing hypothesis of oak forest dynamics across eastern North America, Ecography, 34, 244-256, 2011.

Meko, D., Cook, E. R., Stahle, D. W., Stockton, C. W., and Hughes, M. K.: Spatial patterns of tree-growth anomalies in the United States and southeastern Canada, J. Climate, 6, 1773-1786, 1993.

Menking, K. M., Peteet, D. M., and Anderson, R. Y.: Late-glacial and Holocene vegetation and climate variability, including major droughts, in the Sky Lakes region of southeastern New York State, Palaeogeogr. Palaeocl., 353, 45-59, 2012.

Meyers, P. A.: Applications of organic geochemistry to paleolimnological reconstructions: a summary of examples from the Laurentian Great Lakes, Org. Geochem., 34, 261-289, 2003.

Mitchell, E. A., Charman, D. J., and Warner, B. G.: Testate amoebae analysis in ecological and paleoecological studies of wetlands: past, present and future, Biodivers. Conserv., 17, 21152137, 2008.
Mock, C. J.: Tropical cyclone variations in Louisiana, USA, since the late eighteenth century, Geochem. Geophy. Geosy., 9, Q05V02, https://doi.org/10.1029/2007GC001846, 2008.

Mock, C. J.: Early-Instrumental and Documentary Evidence of Environmental Change, 345-360, 2012.

Morris, P. J., Baird, A. J., Young, D. M., and Swindles, G. T.: Untangling climate signals from autogenic changes in long-term peatland development, Geophys. Res. Lett., 42, 788-797, 2015.

Mullins, H. T. and Halfman, J. D.: High-resolution seismic reflection evidence for middle Holocene environmental change, Owasco Lake, New York, Quaternary Res., 55, 322-331, 2001.

Newby, P., Donnelly, J. P., Shuman, B., and MacDonald, D.: Evidence of centennial-scale drought from southeastern Massachusetts during the Pleistocene/Holocene transition, Quaternary Sci. Rev., 28, 1675-1692, 2009.

Newby, P. E., Shuman, B. N., Donnelly, J. P., Karnauskas, K. B., and Marsicek, J.: Centennial-to-millennial hydrologic trends and variability along the North Atlantic Coast, USA, during the Holocene, Geophys. Res. Lett., 41, 2014GL060183, https://doi.org/10.1002/2014GL060183, 2014.

Nichols, J. E. and Huang, Y.: Hydroclimate of the northeastern United States is highly sensitive to solar forcing, Geophys. Res. Lett., 39, L04707, https://doi.org/10.1029/2011GL050720, 2012.

Noren, A., Bierman, P., Steig, E., Lini, A., and Southon, J.: Millennial-scale Storminess Variability in the Northeastern United States during the Holocene Epoch, Nature, 419, 821-824, 2002.

Oswald, W. and Foster, D.: Middle-Holocene dynamics of Tsuga canadensis (eastern hemlock) in northern New England, USA, Holocene, 22, 71-78, 2012.

Oswald, W., Faison, E. K., Foster, D. R., Doughty, E. D., Hall, B. R., and Hansen, B.: Post-glacial changes in spatial patterns of vegetation across southern New England, J. Biogeogr., 34, 900-913, 2007.

Otto-Bliesner, B. L., Brady, E. C., Fasullo, J., Jahn, A., Landrum, L., Stevenson, S., Rosenbloom, N., Mai, A., and Strand, G.: Climate variability and change since $850 \mathrm{CE}$ : an ensemble approach with the community earth system model (CESM), B. Am. Meteorol. Soc., 97, 735-754, https://doi.org/10.1175/BAMS-D-1400233.1, 2015.

Parris, A. S., Bierman, P. R., Noren, A. J., Prins, M. A., and Lini, A.: Holocene paleostorms identified by particle size signatures in lake sediments from the northeastern United States, J. Paleolimnol., 43, 29-49, 2010.

Parshall, T., Foster, D., Faison, E., MacDonald, D., and Hansen, B.: Long-term history of vegetation and fire in pitch pine-oak forests on Cape Cod, Massachusetts, Ecology, 84, 736-748, 2003.

Pederson, D. C., Peteet, D. M., Kurdyla, D., and Guilderson, T.: Medieval Warming, Little Ice Age, and European impact on the environment during the last millennium in the lower Hudson Valley, New York, USA, Quaternary Res., 63, 238-249, 2005.

Pederson, N., Cook, E. R., Jacoby, G. C., Peteet, D. M., and Griffin, K. L.: The influence of winter temperatures on the annual radial growth of six northern range margin tree species, Dendrochronologia, 22, 7-29, 2004.

Pederson, N., Bell, A. R., Cook, E. R., Lall, U., Devineni, N., Seager, R., Eggleston, K., and Vranes, K. P.: Is an Epic Pluvial Masking the Water Insecurity of the Greater New York City Region?, J. Climate, 26, 1339-1354, 2013. 
Pederson, N., Dyer, J. M., McEwan, R. W., Hessl, A. E., Mock, C. J., Orwig, D. A., Rieder, H. E., and Cook, B. I.: The legacy of episodic climatic events in shaping temperate, broadleaf forests, Ecol. Monogr., 84, 599-620, 2014.

Pederson, N., D’Amato, A. W., Dyer, J. M., Foster, D. R., Goldblum, D., Hart, J. L., Hessl, A. E., Iverson, L. R., Jackson, S. T., Martin-Benito, D., McCarthy, B. C., McEwan, R. W., Mladenoff, D. J., Parker, A. J., Shuman, B., and Williams, J. W.: Climate remains an important driver of post-European vegetation change in the eastern United States, Glob. Change Biol., 21, 2105-2110, 2015.

Peteet, D. M.: Modern pollen rain and vegetational history of the Malaspina Glacier District, Alaska, Quaternary Res., 25, 100120, 1986.

Peterson, T. C., Heim Jr., R. R., Hirsch, R., Kaiser, D. P., Brooks, H., Diffenbaugh, N. S., Dole, R. M., Giovannettone, J. P., Guirguis, K., Karl, T. R., and Katz, R. W.: Monitoring and understanding changes in heat waves, cold waves, floods, and droughts in the United States: state of knowledge, B. Am. Meteorol. Soc., 94, 821-834, 2013.

Pitcher, A., Hopmans, E. C., Mosier, A. C., Park, S.-J., Rhee, S.K., Francis, C. A., Schouten, S., and Damsté, J. S. S.: Core and intact polar glycerol dibiphytanyl glycerol tetraether lipids of ammonia-oxidizing archaea enriched from marine and estuarine sediments, Appl. Environ. Microb, 77, 3468-3477, 2011.

Plank, C. and Shuman, B.: Drought-driven changes in lake areas and their effects on the surface energy balance of Minnesota's lake-dotted landscape, J. Climate, 22, 4055-4065, 2009.

Portmann, R. W., Solomon, S., and Hegerl, G. C.: Spatial and seasonal patterns in climate change, temperatures, and precipitation across the United States, P. Natl. Acad. Sci. USA, 106, 73247329, 2009.

Powers, L. A., Werne, J. P., Johnson, T. C., Hopmans, E. C., Damsté, J. S. S., and Schouten, S.: Crenarchaeotal membrane lipids in lake sediments: A new paleotemperature proxy for continental paleoclimate reconstruction?, Geology, 32, 613-616, 2004.

Prahl, F. and Wakeham, S.: Calibration of unsaturation patterns in long-chain ketone compositions for palaeotemperature assessment, Nature, 330, 367-369, 1987.

Prentice, C. I., Bartlein, P. J., and Webb III, T.: Vegetation and climate change in eastern North America since the Last Glacial Maximum, Ecology, 72, 2038-2056, 1991.

Pribyl, P. and Shuman, B. N.: A computational approach to Quaternary lake-level reconstruction applied in the central Rocky Mountains, Wyoming, USA, Quaternary Res., 82, 249-259, 2014.

Primack, D., Imbres, C., Primack, R., Miller-Rushing, A., and Del Tredici, P.: Herbarium specimens demonstrate earlier flowering times in response to warming in Boston, Am. J. Bot., 91, 1260-1264, 2004.

Ravelo, A. C. and Hillaire-Marcel, C.: Chapter Eighteen the use of oxygen and carbon isotopes of foraminifera in Paleoceanography, Dev. Mar. Geol., 1, 735-764, 2007.

Reid, C.: The origin of the British flora, Dulau \& Company, 191 pp., 1899.

Rühland, K. M., Paterson, A. M., and Smol, J. P.: Lake diatom responses to warming: reviewing the evidence, J. Paleolimnol., 54, $1-35,2015$.
Sachs, J. P.: Cooling of Northwest Atlantic slope waters during the Holocene, Geophys. Res. Lett., 34, L03609, https://doi.org/10.1029/2006GL028495, 2007.

Sachse, D., Radke, J., and Gleixner, G.: Hydrogen isotope ratios of recent lacustrine sedimentary n-alkanes record modern climate variability, Geochim. Cosmochim. Ac., 68, 4877-4889, 2004.

Sachse, D., Billault, I., Bowen, G. J., Chikaraishi, Y., Dawson, T. E., Feakins, S. J., Freeman, K. H., Magill, C. R., McInerney, F. A., van der Meer, M. T. J., Polissar, P., Robins, R. J., Sachs, J. P., Schmidt, H.-L., Sessions, A. L., White, J. W. C., West, J. B., and Kahmen, A.: Molecular paleohydrology: Interpreting the hydrogen-isotopic composition of lipid biomarkers from photosynthesizing organisms, Ann. Rev. Earth Pl. Sc., 40, 221-249, 2012.

Saros, J. and Anderson, N.: The ecology of the planktonic diatom Cyclotella and its implications for global environmental change studies, Biol. Rev., 90, 522-541, 2015.

Saros, J. E., Stone, J. R., Pederson, G. T., Slemmons, K. E., Spanbauer, T., Schliep, A., Cahl, D., Williamson, C. E., and Engstrom, D. R.: Climate-induced changes in lake ecosystem structure inferred from coupled neo-and paleoecological approaches, Ecology, 93, 2155-2164, 2012.

Schouten, S., Hopmans, E. C., Schefuß, E., and Damste, J. S. S.: Distributional variations in marine crenarchaeotal membrane lipids: a new tool for reconstructing ancient sea water temperatures?, Earth Planet. Sc. Lett., 204, 265-274, 2002.

Schouten, S., Hopmans, E. C., and Damsté, J. S. S.: The organic geochemistry of glycerol dialkyl glycerol tetraether lipids: a review, Org. Geochem., 54, 19-61, 2013.

Shuman, B. and Donnelly, J. P.: The influence of seasonal precipitation and temperature regimes on lake levels in the northeastern United States during the Holocene, Quaternary Res., 65, 44-56, 2006.

Shuman, B. and Marsicek, J.: The structure of Holocene climate change in mid-latitude North America, Quaternary Sci. Rev., 141, 38-51, 2016.

Shuman, B., Webb III, T., Bartlein, P. J., and Williams, J. W.: The anatomy of a climatic oscillation: Vegetation change in eastern North America during the Younger Dryas chronozone, Quaternary Sci. Rev., 21, 1777-1791, 2002.

Shuman, B., Newby, P., Huang, Y., and Webb, T.: Evidence for the close climatic control of New England vegetation history, Ecology, 85, 1297-1310, 2004

Shuman, B. N., Newby, P., and Donnelly, J. P.: Abrupt climate change as an important agent of ecological change in the Northeast US throughout the past 15,000 years, Quaternary Sci. Rev., 28, 1693-1709, 2009.

Smith, A. J., Donovan, J. J., Ito, E., Engstrom, D. R., and Panek, V. A.: Climate-driven hydrologic transients in lake sediment records: multiproxy record of mid-Holocene drought, Quaternary Sci. Rev., 21, 625-646, 2002.

Solomon, A. and Webb, T. I.: Computer-aided reconstruction of late-Quaternary landscape dynamics. Annual Review of Ecology and Systematics, Annu. Rev. Ecol. Syst., 16, 63-84, 1985.

Speer, J. H.: Fundamentals of tree-ring research, University of Arizona Press, 2010.

Stahle, D. W. and Hehr, J. G.: Dendroclimatic relationships of post oak across a precipitation gradient in the southcentral United States, Ann. Assoc. Am. Geogr., 74, 561-573, 1984. 
Stahle, D. W., Cleaveland, M. K., Blanton, D. B., Therrell, M. D., and Gay, D. A.: The lost colony and Jamestown droughts, Science, 280, 564-567, 1998.

Stahle, D. W., Fye, F. K., Cook, E. R., and Griffin, R. D.: Tree-ring reconstructed megadroughts over North America since AD 1300, Climatic Change, 83, 133-149, 2007.

Steinman, B. A. and Abbott, M. B.: Isotopic and hydrologic responses of small, closed lakes to climate variability: Hydroclimate reconstructions from lake sediment oxygen isotope records and mass balance models, Geochim. Cosmochim. Ac., 105, 342$359,2013$.

Swain, A. M.: Environmental Changes during the Past 2000 Years in North-Central Wisconsin: Analysis of Pollen, Charcoal, and Seeds from Varved Lake Sediments, Quarternary Res., 10, 5568, 1978.

Swindles, G. T., Morris, P. J., Baird, A. J., Blaauw, M., and Plunkett, G.: Ecohydrological feedbacks confound peat-based climate reconstructions, Geophys. Res. Lett., 39, L11401, https://doi.org/10.1029/2012GL051500, 2012.

Telford, R. and Birks, H.: Evaluation of transfer functions in spatially structured environments, Quaternary Sci. Rev., 28, 13091316, 2009.

Therrell, M. D. and Bialecki, M. B.: A multi-century tree-ring record of spring flooding on the Mississippi River, J. Hydrol., 529, 490-498, 2015.

Tingley, M. and Huybers, P.: A Bayesian Algorithm for Reconstructing Climate Anomalies in Space and Time, J. Climate, 2759-2781,https://doi.org/10.1175/2009JCLI3015.1, 2009.

Tingley, M. P., Craigmile, P. F., Haran, M., Li, B., Mannshardt, E., and Rajaratnam, B.: Piecing together the past: statistical insights into paleoclimatic reconstructions, Quaternary Sci. Rev., 35, 122, 2012.

Tipple, B. J., Berke, M. A., Doman, C. E., Khachaturyan, S., and Ehleringer, J. R.: Leaf-wax n-alkanes record the plant-water environment at leaf flush, P. Natl. Acad. Sci. USA, 110, 2659-2664, 2013.

Tipton, J., Hooten, M., Pederson, N., Tingley, M., and Bishop, D.: Reconstruction of late Holocene climate based on tree growth and mechanistic hierarchical models, Environmetrics, 27, 42-54, 2016.

Trouet, V., Diaz, H. F., Wahl, E. R., Viau, A. E., Graham, R., Graham, N., and Cook, E. R.: A 1500-year reconstruction of annual mean temperature for temperate North America on decadalto-multidecadal time scales, Environ. Res. Lett., 8, 024008, https://doi.org/10.1088/1748-9326/8/2/024008, 2013.

Trouet, V., Harley, G. L., and Domínguez-Delmás, M.: Shipwreck rates reveal Caribbean tropical cyclone response to past radiative forcing, P. Natl. Acad. Sci. USA, 3169-3174, https://doi.org/10.1073/pnas.1519566113, 2016.

Umbanhowar, C. E.: Interaction of fire, climate and vegetation change at a large landscape scale in the Big Woods of Minnesota, USA, Holocene, 14, 661-676, 2004.

Viau, A. E., Gajewski, K., Sawada, M. C., and Fines, P.: Millennial-scale temperature variations in North America during the Holocene, J. Geophys. Res., 111, D09102, https://doi.org/10.1029/2005JD006031, 2006.

Viau, A. E., Ladd, M., and Gajewski, K.: The climate of North America during the past 2000 years reconstructed from pollen data, Global Planet. Change, 84-85, 75-83, 2012.
Wahl, E. R., Diaz, H. F., and Ohlwein, C.: A pollen-based reconstruction of summer temperature in central North America and implications for circulation patterns during medieval times, Global Planet. Change, 84, 66-74, 2012.

Webb, T. I.: Corresponding patterns of pollen and vegetation in lower Michigan: A comparison of quantitative data, Ecology, 55, 17-28, 1974.

Webb, T. I., Bartlein, P. J., and Kutzbach, J. E.: Climatic change in eastern North America during the past 18,000 years: Comparisons of pollen data with model results, Geological Society of America, Boulder, CO, 447-462, 1987.

Webb, R. S., Anderson, K. H., and Webb, T. I.: Pollen responsesurface estimates of late-Quaternary changes in the moisture balance of the northeastern United States, Quaternary Res., 40, 213 227, 1993.

Webb, T. I., Anderson, K., Bartlein, P., and Webb, R.: Late Quaternary climate change in eastern North America: a comparison of pollen-derived estimates with climate model results, Quaternary Sci. Rev., 17, 587-606, 1998.

Webster, K., Creed, I., Nicholas, N., and Van Miegroet, H.: Exploring interactions between pollutant emissions and climatic variability in growth of red spruce in the Great Smoky Mountains National Park, Water Air Soil Poll., 159, 225-248, 2004.

Weider, K. and Boutt, D. F.: Heterogeneous water table response to climate revealed by 60 years of ground water data, Geophys. Res. Lett., 37, L24405, https://doi.org/10.1029/2010GL045561, 2010.

Whitmore, J., Gajewski, K., Sawada, M., Williams, J., Shuman, B., Bartlein, P., Minckley, T., Viau, A., Webb, T., Shafer, S., Anderson, P., and Brubaker, L.: Modern pollen data from North America and Greenland for multi-scale paleoenvironmental applications, Quaternary Sci. Rev., 24, 1828-1848, 2005.

Wigdahl-Perry, C. R., Saros, J. E., Schmitz, J., Calcote, R., Rusak, J., Anderson, D., and Hotchkiss, S.: Response of temperate lakes to drought: a paleolimnological perspective on the landscape position concept using diatom-based reconstructions, J. Paleolimnol., 55, 339-356, 2016.

Williams, J. and Shuman, B.: Obtaining accurate and precise environmental reconstructions from the modern analog technique and North American surface pollen dataset, Quaternary Sci. Rev., 27, 669-687, 2008.

Williams, J., Shuman, B., and Bartlein, P.: Rapid responses of the prairie-forest ecotone to early Holocene aridity in midcontinental North America, Global Planet. Change, 66, 195-207, 2009.

Williams, J. W., Webb, T., Shuman, B. N., and Bartlein, P. J.: Do low $\mathrm{CO}_{2}$ concentrations affect pollen-based reconstructions of LGM climates? A response to "Physiological significance of low atmospheric $\mathrm{CO}_{2}$ for plant-climate interactions" by Cowling and Sykes (vol 53, pg 402, 2000), Quaternary Res., 54, 161-161, 2000.

Williams, J. W., Post, D. M., Cwynar, L. C., Lotter, A. F., and Levesque, A. J.: Rapid and widespread vegetation responses to past climate change in the North Atlantic region, Geology, 30, 971-974, 2002.

Williams, J. W., Shuman, B. N., Webb, T., Bartlein, P. J., and Leduc, P. L.: Late-Quaternary vegetation dynamics in North America: Scaling from taxa to biomes, Ecol. Monogr., 74, 309-334, 2004. 
Williams, J. W., Shuman, B., Bartlein, P. J., Whitmore, J., Gajewski, K., Sawada, M., Minckley, T., Shafer, S., Viau, A. E., Webb, T. I., Anderson, P. M., Brubaker, L. B., Whitlock, C., and Davis, O. K.: An Atlas of Pollen-Vegetation-Climate Relationships for the United States and Canada, American Association of Stratigraphic Palynologists Foundation, Dallas, TX, 2006.

Williams, J. W., Tarasov, P., Brewer, S., and Notaro, M.: Late Quaternary variations in tree cover at the northern forest-tundra ecotone, J. Geophys. Res.-Biogeo., 116, G01017, https://doi.org/10.1029/2010JG001458, 2011.
Winter, T. C.: Relation of streams, lakes, and wetlands to groundwater flow systems, Hydrogeol. J., 7, 28-45, 1999.

Woodward, F. I.: Climate and Plant Distribution, Cambridge University Press, Cambridge, 1987.

Wu, H., Guiot, J., Brewer, S., and Guo, Z.: Climatic changes in Eurasia and Africa at the last glacial maximum and midHolocene: reconstruction from pollen data using inverse vegetation modelling, Clim. Dynam., 29, 211-229, 2007. 